\title{
Water-column nitrate enrichment promotes decline of eelgrass Zostera marina: evidence from seasonal mesocosm experiments
}

\author{
JoAnn M. Burkholder, Katherine M. Mason, Howard B. Glasgow, Jr
}

Department of Botany, Box 7612, North Carolina State University, Raleigh, North Carolina 27695-7612, USA

\begin{abstract}
We imposed a replicated gradient of water-column nitrate enrichment in large-scale experimental mesocosms to test the response of eelgrass to nitrate loading during the spring and fall growing seasons. In spring, controls without nitrate additions $\left(<1 \mu \mathrm{M}\right.$ ambient $\left.\mathrm{NO}_{3}{ }^{-} \mathrm{N}\right)$ were compared to treatments with pulsed daily additions of low (LOW), moderate (MOD), and high (HIGH) enrichment (ca 3.5, 7.0, and 35.0 $\mu \mathrm{M} \mathrm{NO}_{3}^{-}-\mathrm{N} \mathrm{d}^{-1}$, respectively). Under low water exchange simulating quiet embayments, eelgrass growth and survival significantly decreased at all enrichment levels, with most rapid decline at the highest nitrate loadings. Plant death was preceded by loss of structural integrity in the aboveground meristems. The adverse effects of nitrate enrichment in spring apparently were exacerbated by increasing/high temperatures and by macroalgal growth which reduced light comparably over time in all mesocosms. During fall we maintained identical treatments except that the former $\mathrm{HIGH}$ regime was used to test the response of eelgrass to residual sediment $\mathrm{N}_{1}$ accumulation (RES) without additional enrichments. Eelgrass survival was significantly higher in controls and the RES treatment than under MOD enrichment. Nitrate-enriched plants maintained higher $\mathrm{N}$ uptake/storage in the aboveground tissue, but lower carbon storage in the rhizomes. The data indicate that water-column nitrate enrichment causes decline of eelgrass especially under increasing/high temperatures, as a direct physiological effect unrelated to algal light attenuation. The mechanism likely involves internal imbalances in nutrient supply ratios resulting from sustained nitrate uptake through the leaf tissue.
\end{abstract}

\section{INTRODUCTION}

Within the past few decades, catastrophic losses of thousands of hectares of seagrass habitat have occurred throughout the world (Cambridge \& McComb 1984, Orth et al. 1986, Gieson et al. 1990). Among the factors most frequently correlated with the disappearance of seagrass meadows are nutrient enrichment from sewage and agricultural drainage, and reduction in available light from floating and epiphytic algae (Borum 1985, Twilley et al. 1985, Orth et al. 1986, Wetzel \& Neckles 1986). The effects of cultural eutrophication on seagrass survival would be expected to change with season, depending on growth periods for the seagrass communities, seasonal shifts in species dominance, and the duration of perturbations. In Chesapeake Bay, USA, for example, eelgrass Zostera marina L. maintained high production during periods of maxi- mum turbidity and nutrient input associated with agricultural runoff during spring, followed by sudden dieoff in early summer under subcritical temperatures, reduced nutrient loading, high grazing on nuisance shading algae, and increased water clarity (Kemp et al. 1983, Orth et al. 1986, Neckles 1990). Along a nitrate gradient in an estuary in Denmark with influent sewage and agricultural drainage, epiphyte biomass on eelgrass increased 100 -fold in the most enriched locations during summer, and this algal growth was implicated in the decline of the host plants (Borum 1985). In a coastal lagoon in New England, USA, eelgrass production during the spring growing season was stimulated by water-column enrichments of ammonium and phosphate (Harlin \& Thorne-Miller 1981); similarly, in Chesapeake Bay mixed nutrient enrichment of the sediments enhanced eelgrass growth during spring (Orth 1977). 
Under sustained nutrient enrichment and moderate or high water exchange, herbivores can effectively control epiphyte biomass (Orth \& van Montfrans 1984 Neckles 1990). But in quiet upper embayments and coastal lagoons, epiphytes and macroalgae respond so quickly to water-column enrichment that they can seasonally outgrow grazing pressure, leading to severe light reduction and decline of the underlying seagrass (Harlin \& Thorne-Miller 1981, van Montfrans et al. 1984, Borum 1985). Eutrophication effects on seagrass meadows are most severe in sheltered habitats with reduced tidal flushing, where nutrient loadings are both concentrated and frequent, and where temperatures fluctuate more widely than in areas with greater water exchange (Harlin \& Thorne-Miller 1981, Stevenson 1988, Maier \& Pregnall 1990). High summer temperatures can act synergistically with light reduction to increase respiration, adversely affect enzymes involved in general metabolism, and sufficiently weaken the seagrass plants for invasion by disease organisms (Short et al. 1988, Zimmerman et al. 1989), while also stimulating rapid growth of epiphytes and thick mats of floating macroalgae under nutrient enrichment (Harlin \& Thorne-Miller 1981, Borum 1985).

The majority of the phosphate and ammonium from anthropogenic sources tends to adsorb to particulates (Alberts \& Moldenhauer 1981, Grobbelaär 1983, Froelich 1988, Simon 1989). One nutrient present in great abundance and readily available form for plant uptake is the highly soluble nitrate (Craig \& Kuenzler 1983, Jacobs \& Gilliam 1985, Stanley 1988, Maier \& Pregnall 1990). Most seagrasses obtain inorganic nitrogen $\left(\mathrm{N}_{i}\right.$, as ammonia and nitrate) from nutrient-rich sediments (McRoy \& McMillan 1977, Kenworthy et al. 1982, Thursby \& Harlin 1982, Short \& McRoy 1984, Short 1987). They are also able to take advantage of $\mathrm{N}_{\mathrm{i}}$ when it is available in the overlying water (Short \& McRoy 1984), and apparently do so especially if growing in sandy sediments where concentrations of ammonia and nitrate are low (Pregnall et al. 1987). Eelgrass collected from sandy habitat in New England, for example, exhibited sustained high nitrate uptake under water-column enrichments through a $6 \mathrm{~d}$ experiment with no apparent 'shut-off' mechanism (Roth \& Pregnall 1988).

Along the North Carolina coast of the USA, the dominant seagrass, Zostera marina, lies at the southernmost extension of its range (Thayer et al. 1984) and grows stunted from high temperature stress (Den Hartog 1970 ). Temperatures above $30^{\circ} \mathrm{C}$ have been shown to be detrimental to eelgrass by greatly increasing respiration and impairing enzyme activities (Lambers 1985, Marsh et al. 1986, Zimmerman et al. 1989). Water temperatures in North Carolina coastal waters typically reach 31 to $33^{\circ} \mathrm{C}$ (National Oceanic and Atmos- pheric Administration [NOAA] 1980-1990), and maximum shoot length of $Z$. marina averages only ca $40 \mathrm{~cm}$ (Thayer et al. 1984). Eelgrass response to nitrate enrichment in this southern 'fringe' habitat has not been examined. Accelerating coastal development in North Carolina has been associated with increased nutrient loading from septic effluent leachate (Stanley 1988), and loss of eelgrass habitat in upper embayments has been reported anecdotally in the absence of long-term vegetation maps (Ferguson et al. 1988). Aside from adverse effects related to shading by enhanced macroalgal growth, higher $N_{i}$ availability from coastal eutrophication could benefit eelgrass by alleviating $\mathrm{N}_{\mathrm{i}}$ limitation which reduces plant production under non-limiting light (Orth 1977, Harlin \& Thorne-Miller 1981, but see Zimmerman et al. 1987). Alternatively, if the adverse effects of water-column nitrate enrichment were greater than beneficial effects on $N_{i}$ supplies, then $Z$. marina in its southernmost range might be more susceptible to the additional stress than populations in cooler regions.

In the present research we experimentally imposed a gradient of water-column nitrate enrichment within a series of large-scale mesocosms to investigate the effects of nitrate loading on the eelgrass community. Our original hypothesis was that epiphytic algae would be stimulated by the nitrate additions, resulting in biogenic light attenuation that would promote eelgrass decline. Instead, however, we began to observe a direct adverse effect of nitrate on eelgrass survival, apparently unmediated by epiphytes or other community components. Here we report the long-term influences of increased nitrate supply on eelgrass survival, during both spring and fall growing seasons for Zostera marina in warm North Carolina habitat.

\section{MATERIALS AND METHODS}

The eelgrass mesocosm system: physical/chemical characteristics. The experimental system is located outdoors by the shore of the Southeast Laboratory of the National Marine Fisheries Service (NMFS) on Beaufort Inlet, North Carolina. The system consists of 12 fiberglass mesocosms coated with non-toxic white paint, and each mesocosm is $2 \mathrm{~m}$ in diameter $\times 1 \mathrm{~m}$ in height. Water depth and sediment thickness in the mesocosms during experiments were $0.5 \mathrm{~m}$ and $14 \mathrm{~cm}$, respectively. Running seawater was pumped into the system from a depth of $4 \mathrm{~m}$ (at high tide), at a location upstream from the dock area at NMFS. Ambient nitrate and salinity of the bay water were $<1 \mu \mathrm{M}$ $\mathrm{NO}_{3}{ }^{-}-\mathrm{N}$ and 25 to $33 \%$, respectively, during the experimental periods. Submersible pumps were used to create circular mixing, with current velocities main- 
tained at 5 to $10 \mathrm{~cm} \mathrm{~s}^{-1}$. An aeration system bubbled air into the mesocosms from late afternoon to early morning; aeration prevented the communities, with high plant and animal biomass, from encountering anoxia during warm nights (dissolved oxygen at ca $3.0 \mathrm{mg} \mathrm{l}^{-1}$ or higher with exception of 2 dates at ca $1.5 \mathrm{mg} \mathrm{l}^{-1}$, based on weekly measurements near dawn).

Maximum temperatures during experiments were maintained at $\leq 30^{\circ} \mathrm{C}$ on warmest days, sometimes with use of neutral density shades which reduced photosynthetically active radiation (PAR) by about $30 \%$ while still maintaining light above saturation for eelgrass photosynthesis (>350 $\mu$ Einst $\mathrm{m}^{-2} \mathrm{~s}^{-1}$ at the canopy surface; Dennison \& Alberte 1982, Marsh et al. 1986, Dennison 1987, Zimmerman et al. 1991). Diurnal temperature extremes in the mesocosms were $\leq 6{ }^{\circ} \mathrm{C}$ during both seasons, as compared to $\leq 4^{\circ} \mathrm{C}$ in the embayment. Maximum temperatures reached $31^{\circ} \mathrm{C}$ on 5 dates in both late spring and early fall, as compared to $28^{\circ} \mathrm{C}$ ambient bay water temperatures. However, ambient bay temperatures in North Carolina typically reach $33^{\circ} \mathrm{C}$ in shallow, poorly flushed natural habitat which supports thick eelgrass beds (Thayer et al. 1984), and even in the well-flushed bay water (NOAA 1980-1990).

The sediment consisted of clean dredge sand and salt marsh mud in a 3:1 ratio by volume. To minimize heterogeneity, ca 8 tons of sediment were homogenized with a cement mixer and distributed equally to a depth of ca $14 \mathrm{~cm}$ within the mesocosms. For nearly 1 yr before beginning the seasonal experiments, the sediment was maintained with transplanted eelgrass shoots (ca 500 plants $\mathrm{m}^{-2}$ ) in continuously exchanging bay water (one complete water exchange each $20 \mathrm{~min}$ ). After 6 mo the sediment had become well-colonized by invertebrates. The rich and diverse invertebrate community included approximately 40 species of gastropods, bivalves (with numerous scallops), amphipods, isopods, decapods (including blue crabs), copepods, tanaids, tunicates, and polychaetes. We also identified ca 60 species of epiphytic microalgae and phytoplankton as well as 24 taxa of macroalgae.

Biological characteristics of the mesocosm system. At 10 to $14 \mathrm{~d}$ before beginning each seasonal experiment, we removed all previously transplanted Zostera marina shoots and 'reset' the system with approximately 12000 freshly collected shoots from local unenriched field habitat. Plants were sorted into loose bundles of 5 to 8 shoots, and were maintained in shaded outside water tables with flow-through seawater until they were transplanted (within $2 \mathrm{~d}$ ) into the mesocosms. The loose packing and small bundle size were modifications from field transplanting methodology (Fonseca et al. 1985), and significantly improved survival and growth in the mesocosms (from approximately $33 \%$ survival with tightly packed bundles of 15 shoots to $>78 \%$ with the modified technique). Shoots were transplanted to attain initial densities of $\geq 650$ to 700 shoots $\mathrm{m}^{-2}$, and were allowed to acclimate for 10 to $14 \mathrm{~d}$. One day before initiating the experiments, enclosure walls and macrophytes were cleared of most periphyton and macroalgae. Periodically as necessary during the experiments, macroalgal wall growth was removed (and quantified) to minimize confounding 'wall' or enclosure surface-area effects

Macroinvertebrates were difficult to manipulate reliably, a problem encountered by researchers in other seagrass mesocosm systems (e.g. Neckles 1990). Populations of amphipods in spring, and of both amphipods and small gastropods in fall, had greatly increased prior to initiation of experiments. Over a $72 \mathrm{~h}$ period 7 to $14 \mathrm{~d}$ before transplanting, we reduced their numbers by either flushing with fresh water (spring), or by allowing the systems to develop anoxia (fall). These treatments still left abundant populations especially of amphipods. Other animals recruited into the mesocosms in running seawater for 7 to $10 \mathrm{~d}$ prior to initiating experiments, and their populations slowly reestablished. Herbivory appears to control algal biomass seasonally in some seagrass habitats (Zimmerman et al. 1979, Orth \& van Montfrans 1984, Neckles 1990), and could influence Zostera survival under nitrate enrichment. Hence, during the experiments initial amphipod abundances within the Zostera canopy were considered as a covariate in the data analyses. The mesocosms included higher trophic levels such as fish (small spot, croaker and pipefish) and blue crabs which entered as larval stages in the bay water inoculum. Small crabs were removed (baited and then netted out) when they disturbed the sediments sufficiently to create high turbidity in the overlying water.

Sampling seasons and experimental design. Spring and fall experiments were completed from 26 March to 8 May and from 1 October to 17 December 1990. Eelgrass on the North Carolina coast maintains most active growth from February to early May, followed by dehiscence with less growth during summer, and then a smaller growth maximum during October to December (Penhale 1977, Thayer et al. 1984). The spring experiment was run for $7 \mathrm{wk}$, after which nitrate additions were terminated and the mesocosms were continuously flushed with seawater through the summer. Prior to the fall transplanting, schools of pinfish in the field clipped eelgrass leaves just above the shoot meristem, leaving plants with leaf length of only ca 3 to $5 \mathrm{~cm}$. These small shoots encountered an unusually warm autumn, and the 2 factors in combination delayed the effective growing season for Zostera marina by more than 1 mo. Field growth rates paralleled eel- 
grass growth in our experimental system (Thayer et al. 1984). Hence, we extended the fall experiment to $10 \mathrm{wk}$ to include cooler, more typical seasonal conditions (based on 10 yr mean seasonal temperatures; NOAA 1980-1990).

The experiments followed a randomized block design (Gill 1978) with treatments blocked by distance from the pumped inflow. To simulate exchange rates in a quiet upper embayment, exchange of mesocosm water with fresh seawater was restricted to ca 5 to $10 \%$ of the tank volume per day. The spring experiment included triplicate controls (ambient $\mathrm{NO}_{3}{ }^{-} \mathrm{N}$ at $<1 \mu \mathrm{M}$ or ca $10 \mu \mathrm{g} \mathrm{l}^{-1}$ ) and treatments with pulsed additions of low (LOW), moderate (MOD) and high (HIGH) enrichment $\left(3.5,7.0\right.$, and $35.0 \mu \mathrm{M} \mathrm{NO}_{3}^{-}-\mathrm{N}$ $\mathrm{d}^{-1}$, respectively). These loadings were selected based on published information from coastal systems under eutrophication (Mahoney \& Gibson 1983, Ramus \& Venable 1987, Maier \& Pregnall 1990, Neckles 1990, Mallin et al. 1991, Rudek et al. 1991). Each mesocosm was independent of the others in plumbing of intake and outflow lines, so that there was no treatment cross-contamination. Nitrate was added daily between 08:00 and 10:00 $\mathrm{h}$ when high uptake was expected (Morris 1974, Turpin 1991), whereas water exchange was completed between 16:00 and 18:00 h during late afternoon. At only ca $1 \mathrm{~h}$ after enrichment ca $65 \%$ and ca $50 \%$ of the nitrate added in the LOW and MOD treatments, respectively, had been taken up by the eelgrass communities $0.90 .1 \mu \mathrm{M}$ and $3.1 \pm 0.5 \mu \mathrm{M}$ remaining, respectively, as compared to $0.1 \pm 0.1 \mu \mathrm{M}$ in controls; $\mathrm{n}=6$ sampling dates). The cumulative effect of the HIGH enrichments was more striking; the algae and angiosperms were unable to consume the nitrate added, and $24 \mathrm{~h}$ after additions nitrate was maintained at 140 to $300 \mu \mathrm{M}$. Such levels are similar to nitrate concentrations in septic effluent leaching into eelgrass habitat (e.g. Maier \& Pregnall 1990). During the fall experiment we maintained identical treatments in the same mesocosms, except that nitrate was not added to replicates of the former HIGH treatment. Instead, these mesocosms were used to test the influence of the sediment residual nitrate 'memory' (RES) on Zostera marina growth (Caffrey \& Kemp 1990)

Physical and chemical variables. Environmental variables which were measured routinely included temperature, photosynthetically active radiation (PAR), $\mathrm{pH}$, and water-column. nutrients nitrate $\left(\mathrm{NO}_{3}{ }^{-}-\mathrm{N}\right)$, ammonium $\left(\mathrm{NH}_{4}{ }^{+}-\mathrm{N}\right)$, and total phosphorus (TP). Temperature was monitored daily with minimum/maximum thermometers, and salinity was measured daily with a Reichert refractometer. The $\mathrm{pH}$ was measured weekly in mid-afternoon using an Orion field $\mathrm{pH}$ meter (model SA-250). PAR in the upper eelgrass canopy was recorded daily using a LiCor data logger (model 1000) connected to a submersible $4 \pi$ PAR quantum sensor (model LI-193SA). Readings were taken less frequently at the base of the canopy with increasing macroalgal development. The data were used to estimate mean PAR at the shoot meristem of Zostera marina in combination with biweekly data for macroalgal abundances. Samples for water-column nutrient analyses were collected weekly during the early morning, and prior to addition of $\mathrm{NO}_{3}{ }^{-} \mathrm{N}$ in treatments. Weekly sampling was considered adequate to indicate general differences in nutrient concentrations among controls and treatments, based on data collected at $3 \mathrm{~d}$ intervals during Weeks 3 and 5 during spring. These tests showed a 3 to $4 \%$ change in nutrients from controls and the LOW treatment, and a 7 to $12 \%$ change in $\mathrm{NO}_{3}{ }^{-}-\mathrm{N}$ from the $\mathrm{MOD}$ and $\mathrm{HIGH}$ enrichments over each weekly period. Nitrate was determined on a Technicon autoanalyzer (model II), using the coppercadmium reduction procedure of Parsons et al. (1985). Ammonium was measured with the Solórzano method (Parsons et al. 1985) following modifications of Burkholder \& Sheath (1985) for immediate preservation with phenol. TP was analyzed after acid persulfate digestion (Parsons et al. 1985). In addition, sediment pore-water $\mathrm{NO}_{3}{ }^{-}-\mathrm{N}$ and $\mathrm{NH}_{4}{ }^{+}-\mathrm{N}$ were analyzed $2 \mathrm{wk}$ before initiating the fall experiment to assess residual effects of the spring water-column treatments. Duplicate freshly collected sediment cores were sectioned at $1 \mathrm{~cm}$ intervals, and each section was placed over a supported Gelman AA filter in the upper compartment of a custom-designed centrifuge tube. The pore water was filtered while being centrifuged into the lower tube compartment at $4{ }^{\circ} \mathrm{C}$. Pore-water $\mathrm{NO}_{3}{ }^{-} \mathrm{N}$ and $\mathrm{NH}_{4}{ }^{+}-\mathrm{N}$ were analyzed following $\mathrm{Cu}-\mathrm{Cd}$ reduction and the Solorzano method, respectively. At pore-water $\mathrm{pH}$ of ca 7.8, and using 1:4 sample dilutions under aerobic conditions, any minimal interference from sulfide would have caused $\leq 10 \%$ underestimate of ammonium concentrations (Stumm \& Morgan 1981. Grasshoff et al. 1983)

Biological variables. Aboveground eelgrass growth was measured by the leaf puncture method of Zieman $\&$ Wetzel (1980). Shoots were marked at 4 wk intervals, with randomly selected subsets of 6 to 8 plants (or tags from dead plants) harvested weekly. Since shoots which were robust in appearance were selected for marking, the data represent maximum estimates for growth. Mean growth was overestimated especially under $N$ enrichment. Change in shoot density in each mesocosm was determined by quantifying the total shoots within a marked $0.1 \mathrm{~m}^{2}$ quadrat. Total $\mathrm{C}, \mathrm{P}$, and $\mathrm{N}$ of aboveground and belowground Zostera marina tissue were measured at $3 \mathrm{wk}$ intervals during fall (Analytical Laboratory Service, NCSU). 
Epiphytic microalgae were quantified on the basis of eelgrass surface area at $2 \mathrm{wk}$ intervals following the procedure of Burkholder \& Wetzel (1989). To minimize heterogeneity of colonization with age of plant tissue, analyses were confined to the community from secondouter leaves. Leaves from a minimum of 15 shoots were collected from each mesocosm. Leaf-to-leaf variance within the composite samples was tested using quantitative counts of diatom cells from 15 separate leaves (coefficient of variation $18 \%$ ). Diluted subsamples of the epiphyte community were examined at $600 \times$ under phase contrast with an Olympus IMT inverted microscope using the Utermöhl procedure (Lund et al. 1958). Analyses were restricted to formerly viable cells, designated for eukaryotes if chloroplasts were present or, for prokaryotic blue-green algae, if cells were pigmented.

We estimated percent cover by abundant macroalgae weekly (spring high-growth season) as a nondestructive measure of relative abundance (MuellerDombois \& Ellenberg 1974). In each mesocosm macroalgae from three $0.1 \mathrm{~m}^{2}$ quadrats were harvested at the midpoint and end (fall) or at the end of the experiment (spring) for biomass determinations (as dry weight) of tissue dried at $60^{\circ} \mathrm{C}$, also including the dry weight of macroalgal wall growth which had been harvested $2 \mathrm{wk}$ before the end of the spring experiment. Amphipod herbivores were quantified using a net-trap method (Crowder \& Cooper 1982). One $15 \mathrm{~cm}$ diameter net with enclosed artificial plant was placed in 3 random locations along the mesocosm walls (where lacunar oxygen transport to the sediments was minimal, so as to avoid net dislodgement and flotation) for $2 \mathrm{wk}$ periods. Periodic checks indicated that phytoplankton abundances were low ( $<500$ cells $\mathrm{ml}^{-1}$ ) throughout both experiments.

Statistical analyses. Separate data analyses were completed for the 2 seasonal experiments. Correlation analysis was performed initially by date to examine relationships between eelgrass growth, epiphyte abundances, herbivore densities, macroalgal abundances, $\mathrm{pH}, \mathrm{PAR}$, temperature, lag-effect temperature, and salinity (SAS 1987). After testing for homogeneity of variance (Hartley's test; Gill 1978), data were square root-transformed where appropriate (SAS 1987). Two-way ANOVAs (with blocks and treatments as main effects) were used to detect differences among treatments for abundances of epiphytes, macroalgae, herbivores, and change in eelgrass shoot densities, and also for sediment porewater $\mathrm{NO}_{3}{ }^{-}-\mathrm{N}$ and $\mathrm{NH}_{4}{ }^{+}-\mathrm{N}$ (SAS 1987). Treatment means were compared using Fisher's protected least significant difference test, with a comparison-wise error rate ( $\alpha=0.05$; SAS 1987; Day \& Quinn 1989). Initial abundances of amphipod herbivores were con- sidered as a covariate in repeated measures analysis of treatment effects on eelgrass growth (Gill 1978). Two-way ANOVAs (with blocks and treatments as main effects) were also carried out at each measurement date to compare temperature, 'lag-effect' temperature (taken $7 \mathrm{~d}$ prior to growth measurements), salinity, $\mathrm{pH}, \mathrm{PAR}$, and water-column nutrients $\left(\mathrm{NO}_{3}{ }^{-}-\mathrm{N}\right.$, $\mathrm{NH}_{4}{ }^{+}-\mathrm{N}$, and $\mathrm{TP}$ ). Repeated measures analysis was used to test for differences among treatments over time in $Z$. marina growth, macroalgal relative abundance, and eelgrass tissue N/P and C/N ratios (Rowell \& Walters 1976, SAS 1987, Merideth \& Stehman 1990, Potvin \& Lechowicz 1990).

\section{RESULTS}

\section{The spring experiment: environment and community} components

The spring season was unusually warm, with air and bay-water temperatures $7^{\circ} \mathrm{C}$ and $4^{\circ} \mathrm{C}$ higher than average, respectively $(10 \mathrm{yr}$ means; NOAA 1980-1990). Mesocosm water temperatures gradually increased over the spring season as expected (daily means 13 to $27^{\circ} \mathrm{C}$ ), and salinity tracked precipitation events (range $24 \pm 1 \%$ to $34 \pm 2 \%$, as the mean \pm 1 standard error [SE]; Fig 1). On each sampling date, water temperatures varied by $\leq 1.5^{\circ} \mathrm{C}$ among all mesocosms, and salinities varied by $<2 \%$. By the third week of the experiment, $\mathrm{pH}$ was significantly lower in controls than in all treatments, indicating higher photosynthesis in enriched enclosures $(\mathrm{p}=0.048$; Fig. 1). However, by the end of the experiment, pH was similar in controls and the $\mathrm{HIGH}$ regime. Light gradually declined in all enclosures as macroalgal biomass accumulated (Fig. 1). PAR was higher in controls than in all enrichments at Week $5(p=0.042)$. At Week 6 PAR was comparable in controls and the HIGH treatment, but available light in controls remained significantly higher than in the LOW or MOD enrichments where macroalgal growth was rapidly increasing $(\mathrm{p}<0.053)$. By Week 7 , however, macroalgae had also increased in controls and PAR was comparable among all treatments. Mean PAR within the canopy remained higher than $25 \% I_{\circ}$ (or, $>350 \mu$ Einst $\mathrm{m}^{-2} \mathrm{~s}^{-1}$ ) in all mesocosms throughout the experiment.

Water-column nitrate measured 24 h after pulsed enrichments was significantly greater in the $\mathrm{HIGH}$ treatment than the other enclosures after $1 \mathrm{wk}(\mathrm{p}=$ 0.0001 ), and was also greater in the MOD treatment than in controls or the LOW treatment through about half of the experiment ( $p<0.037$ for each of the first 3 wk; Fig. 2). Nitrate concentrations 24 h after enrichment remained at $<4 \mu \mathrm{M}$ in all but the $\mathrm{HIGH}$ regime 

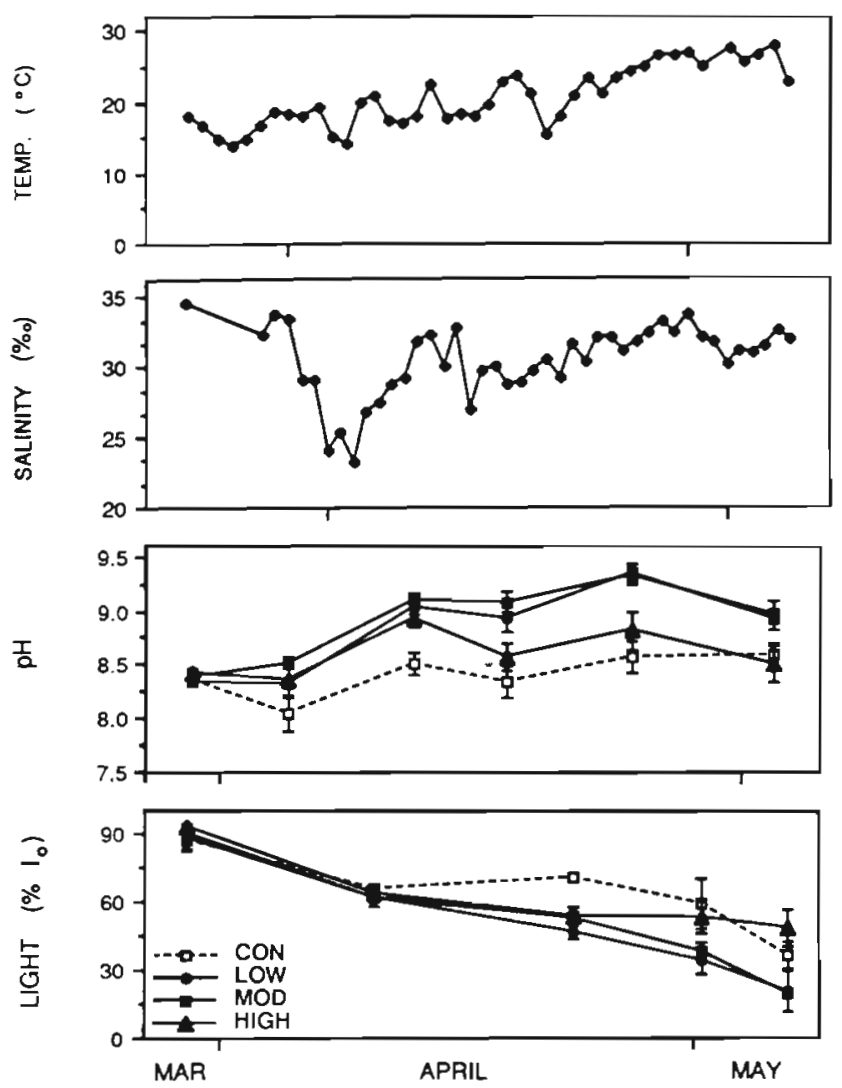

Fig. 1. Temperature, salinity, $\mathrm{pH}$, and PAR at the base of the eelgrass canopy (as percent total PAR just below the surface) during the spring experiment (means $\pm 1 \mathrm{SE}$ )

(range $194 \pm 53 \mu \mathrm{M}$ to $316 \pm 52 \mu \mathrm{M}$ ). Ammonium and phosphorus levels were comparable among all enclosures on most dates. Qualitatively highest TP in controls and lowest TP in the highest nitrate regime indicated that additional water-column phosphorus was removed by the plant communities under nitrate enrichment as N/P supply ratios shifted and algal growth increased (Tilman et al. 1982, Kilham \& Kilham 1984).

Amphipods and epiphytic microalgae were highly variable in abundance, and significant differences were not detected among treatments (Table 1). Herbivore densities were low at the beginning of this experiment, and apparently did not significantly affect abundances of epiphyte microalgae, macroalgae or eelgrass. LOW and MOD enrichments noticeably stimulated macroalgal growth from Weeks 5 to 7 (greater total biomass in LOW enrichment than in the HIGH treatment; $\mathrm{p}<0.056$ for each week; Fig. 3). Relative abundance of macroalgae varied inversely with PAR in controls and all treatments $(p<0.031$ ), indicating that macroalgae gradually reduced available light. Macroalgal response among replicates of a given treatment

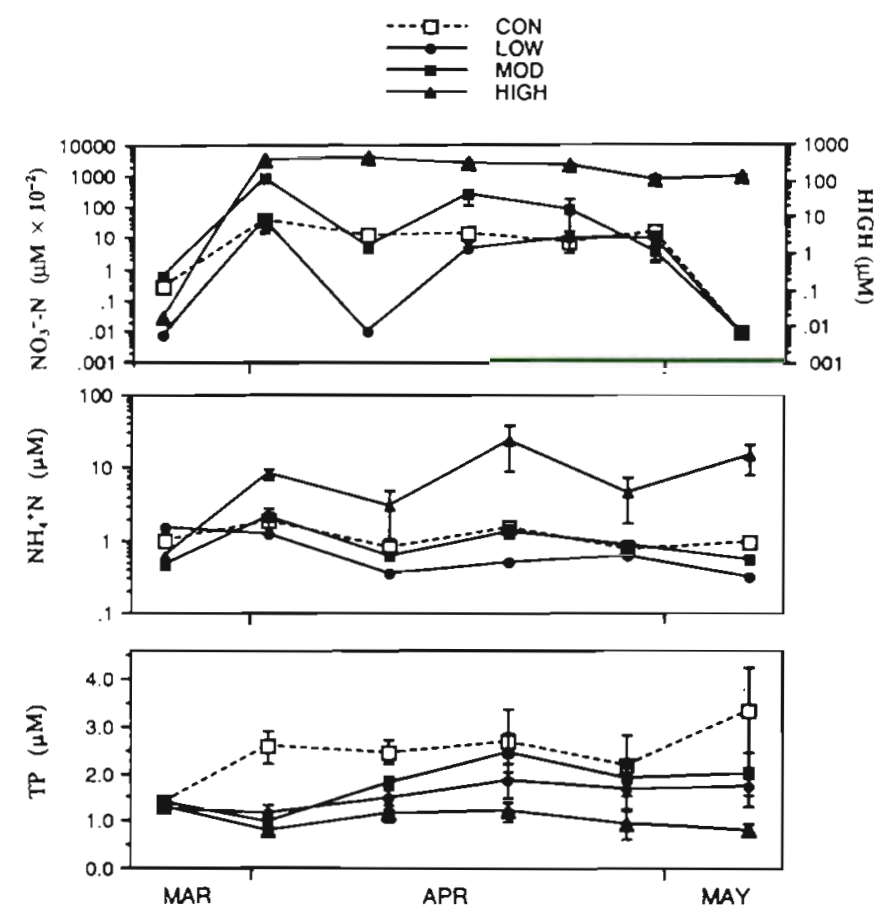

Fig. 2. Nutrient concentrations $\mathrm{NO}_{3}{ }^{-}-\mathrm{N}, \mathrm{NH}_{4}{ }^{+}-\mathrm{N}$ and TP during the spring experiment (means $\pm 1 \mathrm{SE}$ ). Note that $\mathrm{NO}_{3}{ }^{-}-\mathrm{N}$ is plotted for controls and LOW and MOD enrichments on the left ordinate axis $\left(\mu \mathrm{M} \times 10^{-2}\right)$, whereas $\mathrm{NO}_{3}^{-}-\mathrm{N}$ for the $\mathrm{HIGH}$ treatment is plotted on the right ordinate axis $(\mu \mathrm{M})$

varied considerably, however, in both taxa dominance (mostly Entermoropha spp. and Ectocarpus siliculosus Sauvageau) and timing of the response (Fig. 3A).

\section{Eelgrass response in spring}

During the first 7 to $10 \mathrm{~d}$ after spring transplanting, total leaf elongation of eelgrass shoots was ca $1 \mathrm{~cm} \mathrm{~d}^{-1}$ (Fig. 4). Plants were easily separated from the sediment for ca 4 wk after transplanting. At that time (Week 3 of the experiment), the shoots became firmly anchored and dislodged plants had abundant roots, noticeably more than when first planted. This period of apparent energy allocation into root production corresponded to reduced aboveground growth, followed in Week 4 by aboveground growth in controls (ca $1.8 \mathrm{~cm}$ $\mathrm{d}^{-1}$ ) and in the LOW and MOD treatments (mean 0.7 $\mathrm{cm} \mathrm{d} \mathrm{d}^{-1}$ and $1.0 \mathrm{~cm} \mathrm{~d}^{-1}$, respectively). Negligible leaf elongation occurred at $3 \mathrm{wk}$, however, in the HIGH nitrate enrichment.

At Weeks 4 to 5 of the experiment, we made a startling observation: nearly all Zostera marina shoots in the HIGH nitrate regime were bright green and appeared robust, but when we attempted to gently 
Table 1 Abundances of epiphytic algae (primarily diatoms, blue-green algae, cryptomonads and dinoflagellates, as total cells $\times 10^{5} \mathrm{~cm}^{-2}$ ) and amphipod herbivores (individuals $\times 10^{3} \mathrm{~m}^{-2}$ ) during the spring and fall experiments (means $\pm 1 \mathrm{SE}$ )

\begin{tabular}{|c|c|c|c|c|c|}
\hline & Date & Control & LOW & MOD & $\mathrm{HIGH}$ \\
\hline \multicolumn{6}{|l|}{ Spring } \\
\hline Epiphytic microalgae & $\begin{array}{l}26 \mathrm{Mar} \\
24 \mathrm{Apr} \\
8 \mathrm{May}\end{array}$ & $\begin{array}{l}1.25 \pm 0.61 \\
0.65 \pm 0.30 \\
3.36 \pm 0.91\end{array}$ & $\begin{array}{l}1.10 \pm 0.09 \\
0.54 \pm 0.23 \\
6.21 \pm 2.34\end{array}$ & $\begin{aligned} 1.01 & \pm 0.07 \\
1.54 & \pm 0.38 \\
27.60 & \pm 14.96\end{aligned}$ & $\begin{array}{c}2.27 \pm 0.43 \\
2.10 \pm 0.98 \\
30.6\end{array}$ \\
\hline Amphipod herbivores & $\begin{array}{l}26 \mathrm{Mar} \\
24 \mathrm{Apr} \\
8 \mathrm{May}\end{array}$ & $\begin{array}{l}17.1 \pm 12.7 \\
36.6 \pm 31.7 \\
36.4 \pm 24.0\end{array}$ & $\begin{array}{c}3.4 \pm 3.3 \\
9.7 \pm 9.4 \\
41.2 \pm 40.0\end{array}$ & $\begin{array}{c}1.3 \pm 1.2 \\
5.8 \pm 5.6 \\
25.4 \pm 24.6\end{array}$ & $\begin{array}{c}3.4 \pm 2.8 \\
33.7 \pm 28.9 \\
57.8 \pm 33.0\end{array}$ \\
\hline \multicolumn{6}{|l|}{ Fall } \\
\hline Epiphytic microalgae & $\begin{array}{l}16 \mathrm{Oct} \\
12 \mathrm{Nov} \\
10 \mathrm{Dec}\end{array}$ & $\begin{array}{l}7.87 \pm 1.28 \\
2.71 \pm 1.51 \\
0.95 \pm 0.30\end{array}$ & $\begin{array}{r}10.23 \pm 7.00 \\
7.78 \pm 4.26 \\
2.45 \pm 1.15\end{array}$ & $\begin{array}{r}16.65 \pm 1.74 \\
10.91 \pm 6.19 \\
1.26 \pm 0.53\end{array}$ & $\begin{array}{l}9.49 \pm 3.57 \\
2.73 \pm 0.86 \\
0.39 \pm 0.11\end{array}$ \\
\hline Amphipod herbivores & $\begin{array}{l}16 \mathrm{Oct} \\
12 \mathrm{Nov} \\
10 \mathrm{Dec}\end{array}$ & $\begin{array}{l}0.6 \pm 0.2 \\
0.5 \pm 0.4 \\
0.3 \pm 0.2\end{array}$ & $\begin{array}{l}0.3 \pm 0.1 \\
1.4 \pm 0.6 \\
0.9 \pm 0.2\end{array}$ & $\begin{array}{l}0.3 \pm 0.1 \\
1.0 \pm 0.1 \\
0.7 \pm 0.5\end{array}$ & $\begin{array}{l}0.8 \pm 0.5 \\
0.8 \pm 0.3 \\
0.5 \pm 0.2\end{array}$ \\
\hline
\end{tabular}

sever leaves for epiphyte collections, the meristematic region disintegrated - the plants crumbled and literally fell apart in our hands. During Weeks 5 to 7 nearly all of the shoots from the HIGH regime died and collapsed
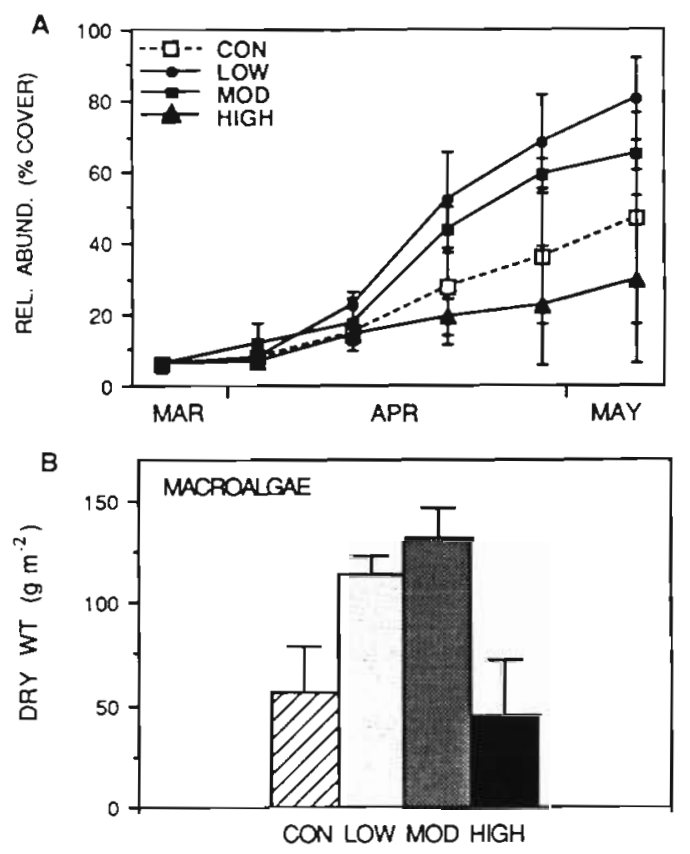

Fig. 3. Total abundance of macroalgae during the spring experiment, as (A) relative abundance, and (B) harvested dry weight per unit surface area at the end of the experiment (means $\pm 1 \mathrm{SE}$ ). Dominant genera in the harvested material were Ectocarpus (controls), Enteromorpha (LOW and MOD enrichments), and mat-forming Spirulina/Lyngbya (HIGH) to the sediment, regardless of abundances of epiphytes, macroalgae, or macroinvertebrate herbivores (eelgrass growth in the HIGH treatment significantly less than in controls [Weeks 5 to 7 ] and significantly
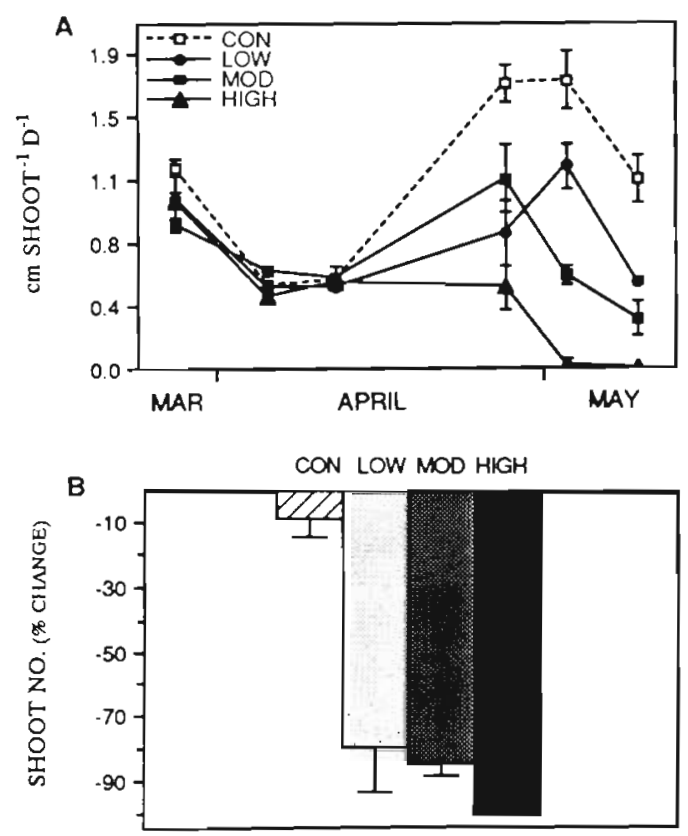

Fig. 4. Zostera marina. Response of eelgrass to water-column nitrate enrichment in the spring experiment, as (A) aboveground growth of eelgrass during the spring experiment (total elongation of all new leaf tissue, as means $\pm 1 \mathrm{SE}$ ); and (B) change in shoot numbers (percent change, means $\pm 1 \mathrm{SE}$ ) 
less than other treatments [Weeks 6 to 7 ] at $p<0.006$ in each week; Fig. 4). After 6 to 7 wk most plants under MOD enrichment exhibited similar deterioration, and growth under both the LOW and MOD treatments was significantly less than in controls $(p<0.037$ in each week $_{i}$ Fig. 4). Under high temperatures during the last week (maxima 27 to $30^{\circ} \mathrm{C}$ ), eelgrass growth declined even in the controls (from $1.6 \mathrm{~cm} \mathrm{~d}^{-1}$ at Week 6 to 1.2 $\mathrm{cm} \mathrm{d}^{-1}$ at Week 7 ). Such declines are typical of the onset of dehiscence in field populations of eelgrass (Thayer et al. 1984).

Over the unusually warm spring, shoot densities decreased slightly (by ca $10 \%$ ) even in the controls (Fig. 4). All plants had disappeared from the HIGH nitrate regime, however, with $99 \pm 1 \%$ reduction in densities. Moreover, in LOW and MOD enrichments eelgrass had declined by $\geq 80 \%$ (all treatments significantly less in shoot density than controls; $p<0.002$ ). The striking decrease in eelgrass growth between controls and $\mathrm{N}$-enriched plants could not be attributed to differences in temperature, salinity, pH, PAR, or abundances of macroalgae, epiphytic microalgae or amphipod herbivores.

After terminating the experiment, we cleared the mesocosms of most macroalgae and then flushed them continuously with running seawater until late August. Nonetheless, by mid-June ca $80 \%$ of the remaining eelgrass in the former LOW and MID treatments had developed high infestation by the opportunistic slime mold-like protozoan Labyrinthula (Newell 1982), and only a few plants remained by late July. In marked contrast, the former control plants were abundant and appeared robust, with low incidence of fungal attack $(<10 \%)$.

\section{The fall experiment: environment and community components}

As in spring, the fall season was also unusually warm, with air and bay-water temperatures $7^{\circ} \mathrm{C}$ and $3^{\circ} \mathrm{C}$ higher than average, respectively $(10 \mathrm{yr}$ means; NOAA 1980-1990). Mesocosm water temperatures gradually decreased but were $>15^{\circ} \mathrm{C}$ throughout most of the experiment (Fig. 5). Salinities were $30 \%$ or higher except following appreciable precipitation, with minima at ca $26 \%$ in late October (Fig. 5). The pH gradually increased and was qualitatively highest in the MOD enrichment and lowest in the RES treatment throughout the fall, but clear differences among treatments were not observed (Fig. 5). Similarly, PAR did not differ among treatments except on one date in early December when developing mats of the green macroalga Chaetomorpha linum (O.F. Müller) Kütz. declined in 2 control replicates. During the following

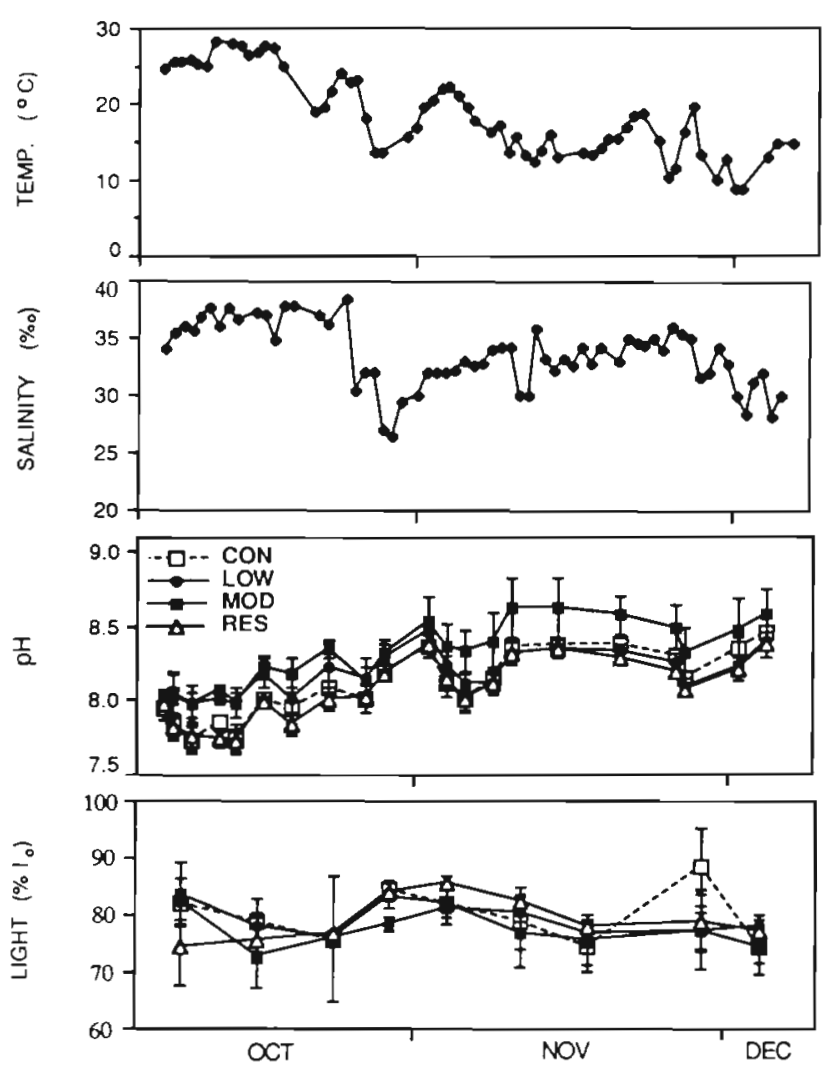

Fig. 5. Temperature, salinity, $\mathrm{pH}_{1}$ and PAR at the base of the canopy during the fall experiment (means $\pm 1 \mathrm{SE}$ )

week, however, C. linum again increased and PAR decreased to comparable levels in the controls as in the treatments.

During both fall and spring, water-column nutrient concentrations were similar in the treatments, except that the RES treatment was not comparable to the former HIGH treatment (Figs. 2 \& 6). Within $24 \mathrm{~h}$ after nitrate additions, water-column $\mathrm{NO}_{3}{ }^{-}-\mathrm{N}$ was highest under MOD enrichment. Ammonium and TP were similar among treatments except during the first half of the fall, when TP was slightly higher in the RES treatment than in treatments with pulsed $\mathrm{NO}_{3}{ }^{-}-\mathrm{N}$ additions (Fig. 6).

Profiles of $\mathrm{N}_{\mathrm{i}}$ in sediment pore water taken $2 \mathrm{wk}$ before the fall experiment indicated that $\mathrm{NO}_{3}{ }^{-}-\mathrm{N}$ from sediment depth 1 to $2 \mathrm{~cm}$ was distinctly lower in the former MOD treatment than in controls or other treatments (Fig. 7). A sharp increase in $\mathrm{NO}_{3}{ }^{-}-\mathrm{N}$ at $10 \mathrm{~cm}$ also occurred in the (former) MOD and especially the $\mathrm{HIGH}$ treatments; these maxima reflected seepage of $\mathrm{NO}_{3}{ }^{-}-\mathrm{N}$ to the base of the mesocosms, well below the eelgrass roots and rhizomes. The presence of $\geq c a 0.1$ $\mu \mathrm{M} \mathrm{NO}{ }^{-}-\mathrm{N}$ throughout the depth profile in all mesocosms suggested that the sediments were microaerobic, attributed to oxygen diffusion from the lacunar 

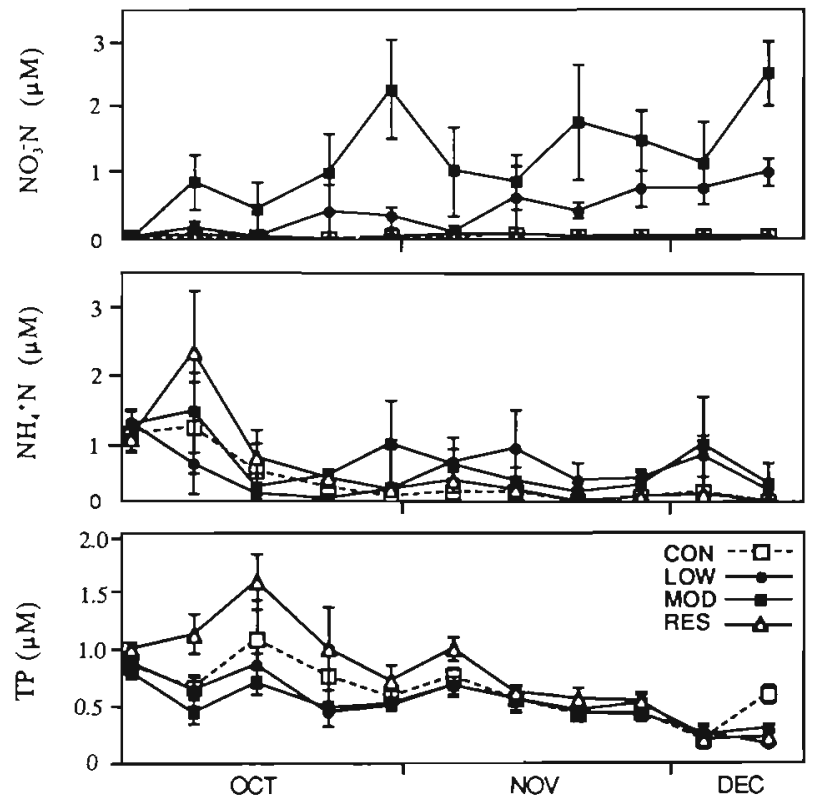

Fig. 6. Nutrient concentrations $\mathrm{NO}_{3}^{-}-\mathrm{N}, \mathrm{NH}_{4}{ }^{+}-\mathrm{N}$ and $\mathrm{TP}$ during the fall experiment system to the rhizosphere, and to burrowing activities of abundant polychaetes and other animals (Penhale \& Wetzel 1982, Kristensen 1988). Ammonium concentrations generally were ca 100 -fold higher than $\mathrm{NO}_{3}{ }^{-} \mathrm{N}$ (Fig. 7), and comparable to (low) values of sediment $\mathrm{NH}_{4}{ }^{+}-\mathrm{N}$ measured from natural eelgrass habitat (Kenworthy et al. 1982). In contrast to the depth profile observed for $\mathrm{NO}_{3}{ }^{-} \mathrm{N}$, under $\mathrm{MOD}$ enrichment an $\mathrm{NH}_{4}{ }^{+}-\mathrm{N}$ maximum of about $120 \mu \mathrm{M}$ occurred near the sediment surface at depth 2 to $3 \mathrm{~cm}$, likely reflecting microbial denitrification (Fig. 7).

As in spring, amphipod herbivores and epiphytic microalgae were highly variable among replicates within a given treatment (Table 1). Significant effects of the highly variable herbivore densities on epiphyte or macroalgal abundances were not discerned among treatments. Macroalgal growth was only $10 \%$ and $30 \%$, respectively, of the biomass produced in the LOW and MOD treatments during spring (Figs. 3 \& 8). Total biomass was comparable among all mesocosms until Week 7 of the experiment, when macroalgae began to increase under MOD enrichment (sig-
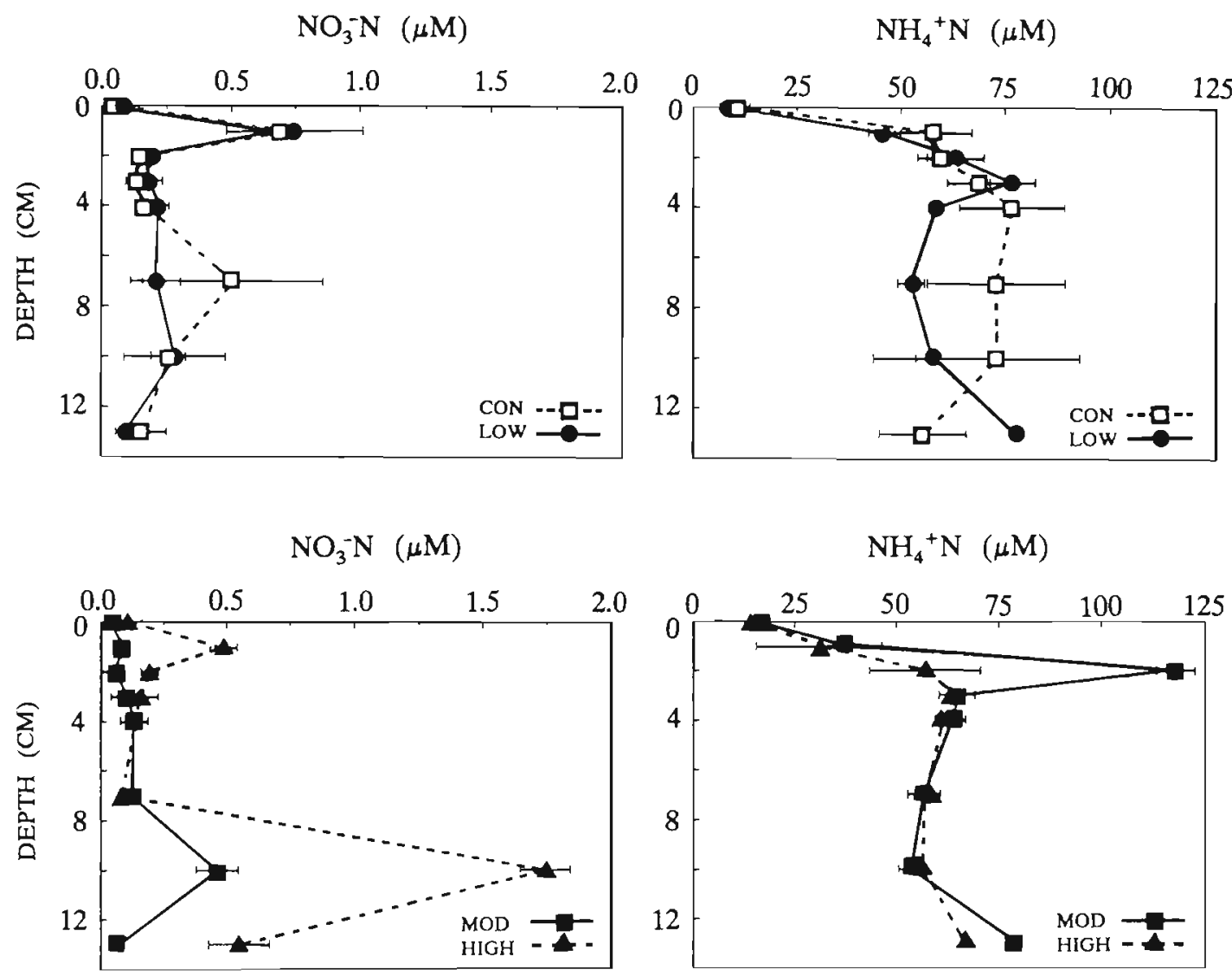

Fig. 7 . Initial $\mathrm{N}_{1}$ regime in the sediment pore-water for the fall experiment, including $\mathrm{NO}_{3}{ }^{-}-\mathrm{N}^{-}$and $\mathrm{NH}_{4}{ }^{+}-\mathrm{N}$ (left and right panels, respectively; means $\pm 1 \mathrm{SE}$ ) 
nificantly higher than in other treatments by the end of the experiment; $p<0.021$ ). As in spring, dominance among taxa (mostly Chaetomorpha linum and Cladophora montagneana Kütz., also with Ectocarpus siliculosus and Enteromorpha spp. in late Nov-Dec) was variable among replicates within a given treatment. Surprisingly, macroalgae showed negligible growth in the RES treatment throughout the fall (less than in controls or other treatments; $p<0.003$; Fig. 8), and minimal macroalgal growth also occurred in the LOW treatment. Autumn epiphyte and macroalgal abundances were not highly correlated with amphipod densities, $\mathrm{pH}$, salinity, temperature, or PAR.
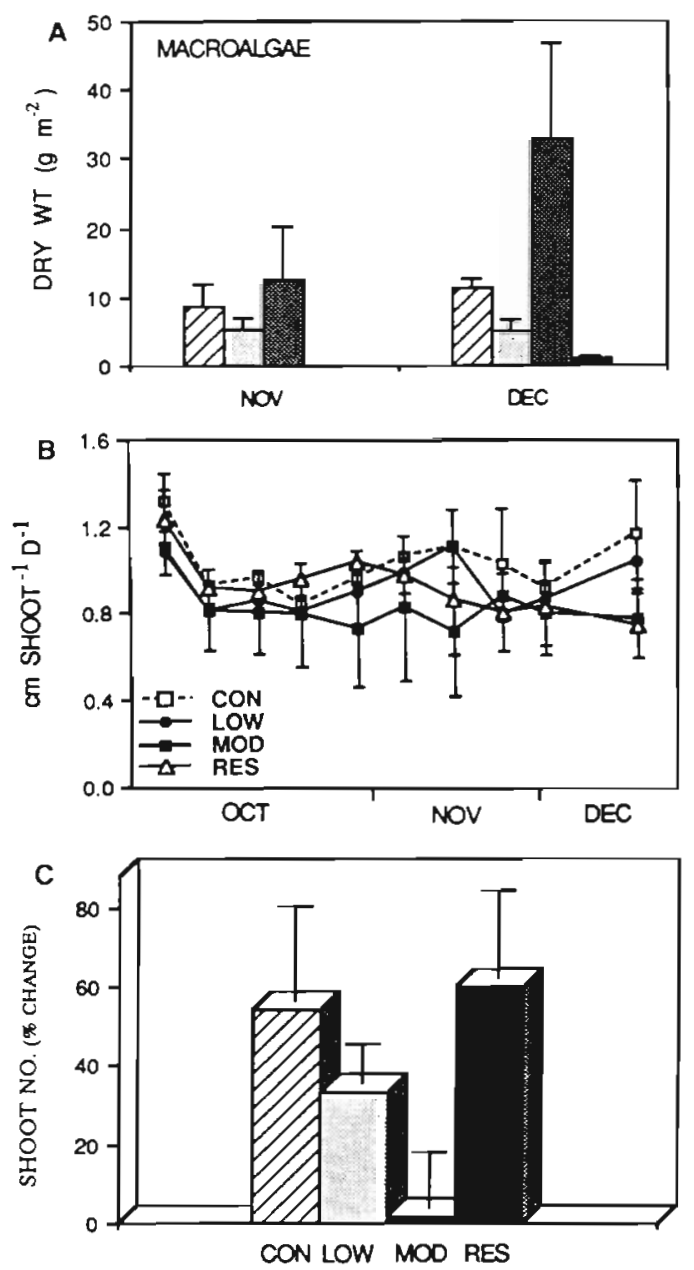

Fig. 8. Response of macroalgae and eelgrass to nitrate enrichment in the fall experiment. (A) Macroalgal abundance as harvested dry weight per unit surface area (means $\pm 1 \mathrm{SE}$ ). Chaetomorpha was abundant throughout the experiment, codominant with Cladophora (Oct through mid-Nov) and Ectocarpus (late Nov-Dec). (B) Aboveground growth of Zostera marina (total elongation of all new leaf tissue, as means $\pm 1 \mathrm{SE}$ ). (C) Change in shoot numbers of $Z$. marina (percent change, means $\pm 1 \mathrm{SE}$ )

\section{Eelgrass response in fall}

Maximum aboveground growth of eelgrass shoots $4 \mathrm{~d}$ after initiating fall treatments was comparable to initial growth during spring $\left(1.0\right.$ to $1.3 \mathrm{~cm} \mathrm{~d}^{-1}$ and 0.9 to $1.2 \mathrm{~cm} \mathrm{~d}^{-1}$ in fall and spring, respectively; Fig. 8). At the end of Week 2 of the experiment, leaf growth decreased among all mesocosms while the plants apparently allocated most energy into root production as in spring. From late October to mid-December, aboveground growth increased or was constant in the controls and the LOW and RES treatments, whereas growth decreased or remained constant under MOD enrichment. High variability occurred among the replicates of the MOD treatment, however; growth in 2 of 3 replicates was much lower than in all other treatments, but some plants in the third replicate were robust and grew rapidly, resulting in coefficients of variation $>50 \%$ on some dates. There was a trend of highest aboveground growth in controls and lowest growth in the MOD treatment (Fig. 8). However, 2-way ANOVA and repeated measures analysis did not yield significant differences in the fall eelgrass growth among the controls and treatments.

As during spring, the aboveground growth measurements were taken from the most robust plants in the treatments and, thus, represent maximum growth estimates. At the population level the adverse effects of water-column nitrate enrichment on eelgrass shoot densities during fall were more striking. In contrast to the spring season, Zostera marina exhibited a positive change in shoot densities (i.e. lateral growth) by the end of fall in controls and all treatments, although in only 1 of 3 mesocosms of the MOD enrichment (Fig. 8). Lateral shoot production was highest in controls and the RES treatment (ca $60 \pm 23 \%$ increase in shoot numbers), qualitatively less in the LOW nitrate regime (32 $\pm 10 \%$ increase), and much lower in the MOD treatment $(2 \pm 14 \%$ increase, with the SE reflecting decreased shoot numbers in 2 replicates; shoot numbers significantly higher in controls and the RES treatment than in MOD enrichment; $p<0.029$ ). This decline in shoot densities was visually obvious in 2 of 3 replicates of the MOD treatment after $6 \mathrm{wk}$ of pulsed daily nitrate additions, and coincided with the period of minimum aboveground growth. At that time, the meristems of remaining shoots became noticeably weakened in structural integrity, and the tissue was easily macerated relative to plants from the lower nitrate regimes. Aboveground shoot growth was not significantly correlated with salinity, PAR, $\mathrm{pH}$, temperature, or abundances of macroalgae, epiphytic microalgae, or amphipod herbivores.

Data on tissue content indicated that by midNovember, eelgrass from the LOW and MOD treat- 
Table 2. Zostera marina. Tissue content (\% dry weight) of $\mathrm{C}, \mathrm{N}$, and $\mathrm{P}$ in aboveground (Above) and belowground (Below) tissue of eelgrass during the fall experiment. Data are given as means \pm 1 SE for 8 to 10 shoots from each mesocosm ( $n=3$ replicate mesocosms per treatment) except for tissue collected in October, when low shoot biomass required pooling the aboveground and belowground tissue of the 24 to 30 shoots from all replicates within each treatment. Asterisks (") indicate significant differences from tissue content in controls (Student $t$-test, $\mathrm{p}<0.05$ )

\begin{tabular}{|c|c|c|c|c|c|}
\hline Date & Tissue & Control & LOW & MOD & RES \\
\hline \multicolumn{6}{|l|}{ Carbon } \\
\hline $16 \mathrm{Oct}$ & $\begin{array}{l}\text { Above } \\
\text { Below }\end{array}$ & $\begin{array}{l}32.84 \\
29.16\end{array}$ & $\begin{array}{l}31.24 \\
29.39\end{array}$ & $\begin{array}{l}27.90 \\
25.00\end{array}$ & $\begin{array}{l}31.47 \\
27.66\end{array}$ \\
\hline 28 Oct & $\begin{array}{l}\text { Above } \\
\text { Below }\end{array}$ & $\begin{array}{l}30.78 \\
29.76 \pm 0.98\end{array}$ & $\begin{array}{l}30.51 \\
31.13 \pm 0.48\end{array}$ & $\begin{array}{l}31.23 \\
29.01 \pm 0.05\end{array}$ & $\begin{array}{l}32.48 \\
28.12 \pm 1.34\end{array}$ \\
\hline $19 \mathrm{Nov}$ & $\begin{array}{l}\text { Above } \\
\text { Below }\end{array}$ & $\begin{array}{l}28.34 \pm 0.21 \\
28.13 \pm 0.35\end{array}$ & $\begin{array}{l}28.50 \pm 0.66 \\
27.20 \pm 0.74\end{array}$ & $\begin{array}{l}26.22 \pm 1.03^{\circ} \\
27.22 \pm 0.31^{\circ}\end{array}$ & $\begin{array}{l}27.53 \pm 0.93 \\
26.61 \pm 0.40\end{array}$ \\
\hline $16 \mathrm{Dec}$ & $\begin{array}{l}\text { Above } \\
\text { Below }\end{array}$ & $\begin{array}{l}30.92 \pm 0.41 \\
27.48 \pm 1.09\end{array}$ & $\begin{array}{l}31.61 \pm 1.00 \\
25.39 \pm 0.66\end{array}$ & $\begin{array}{l}31.77 \pm 0.65 \\
25.49 \pm 0.85\end{array}$ & $\begin{array}{l}31.74 \pm 0.52 \\
27.31 \pm 0.09\end{array}$ \\
\hline \multicolumn{6}{|c|}{ Nitrogen } \\
\hline $16 \mathrm{Oct}$ & $\begin{array}{l}\text { Above } \\
\text { Below }\end{array}$ & $\begin{array}{l}1.84 \\
1.10\end{array}$ & $\begin{array}{l}1.63 \\
0.83\end{array}$ & $\begin{array}{l}1.68 \\
0.75\end{array}$ & $\begin{array}{l}1.85 \\
0.91\end{array}$ \\
\hline 28 Oct & $\begin{array}{l}\text { Above } \\
\text { Below }\end{array}$ & $\begin{array}{l}1.81 \\
0.89 \pm 0.05\end{array}$ & $\begin{array}{l}1.83 \\
0.87 \pm 0.08\end{array}$ & $\begin{array}{l}2.13 \\
1.03 \pm 0.13^{\circ}\end{array}$ & $\begin{array}{l}2.04 \\
0.87 \pm 0.09\end{array}$ \\
\hline 19 Nov & $\begin{array}{l}\text { Above } \\
\text { Below }\end{array}$ & $\begin{array}{l}1.39 \pm 0.08 \\
0.67 \pm 0.10\end{array}$ & $\begin{array}{l}2.01 \pm 0.14^{\circ} \\
0.71 \pm 0.01\end{array}$ & $\begin{array}{l}1.90 \pm 0.06^{\circ} \\
0.87 \pm 0.02^{\circ}\end{array}$ & $\begin{array}{l}1.50 \pm 0.08 \\
0.61 \pm 0.03\end{array}$ \\
\hline $16 \mathrm{Dec}$ & $\begin{array}{l}\text { Above } \\
\text { Below }\end{array}$ & $\begin{array}{l}1.72 \pm 0.04 \\
0.67 \pm 0.04\end{array}$ & $\begin{array}{l}2.60 \pm 0.09^{\circ} \\
0.99 \pm 0.09^{\circ}\end{array}$ & $\begin{array}{l}2.69 \pm 0.24^{\circ} \\
1.07 \pm 0.09^{\circ}\end{array}$ & $\begin{array}{l}2.03 \pm 0.12 \\
0.68 \pm 0.01\end{array}$ \\
\hline \multicolumn{6}{|c|}{ Phosphorus } \\
\hline $16 \mathrm{Oct}$ & $\begin{array}{l}\text { Above } \\
\text { Below }\end{array}$ & $\begin{array}{l}0.22 \\
0.16\end{array}$ & $\begin{array}{l}0.20 \\
0.11\end{array}$ & $\begin{array}{l}0.18 \\
0.11\end{array}$ & $\begin{array}{l}0.20 \\
0.13\end{array}$ \\
\hline $28 \mathrm{Oct}$ & $\begin{array}{l}\text { Above } \\
\text { Below }\end{array}$ & $\begin{array}{l}0.22 \\
0.13 \pm 0.03\end{array}$ & $\begin{array}{l}0.24 \\
0.15 \pm 0.01\end{array}$ & $\begin{array}{l}0.26 \\
0.16 \pm 0.02\end{array}$ & $\begin{array}{l}0.24 \\
0.13 \pm 0.02\end{array}$ \\
\hline $19 \mathrm{Nov}$ & $\begin{array}{l}\text { Above } \\
\text { Below }\end{array}$ & $\begin{array}{l}0.22 \pm 0.01 \\
0.10 \pm 0.01\end{array}$ & $\begin{array}{l}0.20 \pm 0.01 \\
0.09 \pm 0.00\end{array}$ & $\begin{array}{l}0.19 \pm 0.01 \\
0.09 \pm 0.01\end{array}$ & $\begin{array}{l}0.21 \pm 0.02 \\
0.10 \pm 0.00\end{array}$ \\
\hline $16 \mathrm{Dec}$ & $\begin{array}{l}\text { Above } \\
\text { Below }\end{array}$ & $\begin{array}{l}0.39 \pm 0.03 \\
0.16 \pm 0.04\end{array}$ & $\begin{array}{l}0.22 \pm 0.05^{\circ} \\
0.11 \pm 0.01\end{array}$ & $\begin{array}{l}0.29 \pm 0.01^{\circ} \\
0.12 \pm 0.02\end{array}$ & $\begin{array}{l}0.36 \pm 0.06 \\
0.14 \pm 0.01\end{array}$ \\
\hline
\end{tabular}

ments had significantly higher $N$ in their aboveground and belowground tissue ( $p<0.028)$, indicating elevated nitrate uptake relative to plants in the controls and the RES treatment (Table 2). During a warming period in late November when growth had noticeably declined in 2 of 3 replicates of the MOD regime, eelgrass from the MOD treatment had significantly less $C$ than controls in both above-ground and belowground tissue ( $p<0.05$; Table 2). Further, by early December aboveground tissue $\mathrm{P}$ was significantly lower in LOW and MOD enrichments than in the controls ( $p<0.05$ ), although aboveground $P$ in both enriched regimes remained higher than levels indicative of $P$ limitation (Duarte 1990).

These differences in tissue nutrient content were reflected in $\mathrm{C} / \mathrm{N}$ and $\mathrm{N} / \mathrm{P}$ ratios. Eelgrass from both pulse-enriched treatments had significantly higher $\mathrm{N} / \mathrm{P}$ ratios in both aboveground and belowground tissue $(p<0.031$; Fig. 9). The $\mathrm{C} / \mathrm{N}$ ratios of shoots from the LOW and MOD enrichments were similar and steadily decreased in aboveground tissue from means of 18 to 19 in October to $12 \pm 3$ in December; $p<$ 0.052 ), but $\mathrm{C} / \mathrm{N}$ values in belowground tissue of enriched plants did not significantly decrease until December (37 to 38 in October to 19 to 22 in December; $\mathrm{p}<0.038$; Fig. 10). In contrast, control and RES plants showed no change in aboveground $\mathrm{C} / \mathrm{N}$ ratios (ca 18), which were about $30 \%$ higher than those of enriched plants by December. However, the $\mathrm{C} / \mathrm{N}$ ratios of belowground tissue in December were significantly higher than during late October in both controls and the RES treatment (ca $60 \%$ higher than in LOW-MOD plant tissue by December; $p<0.049$ ). 


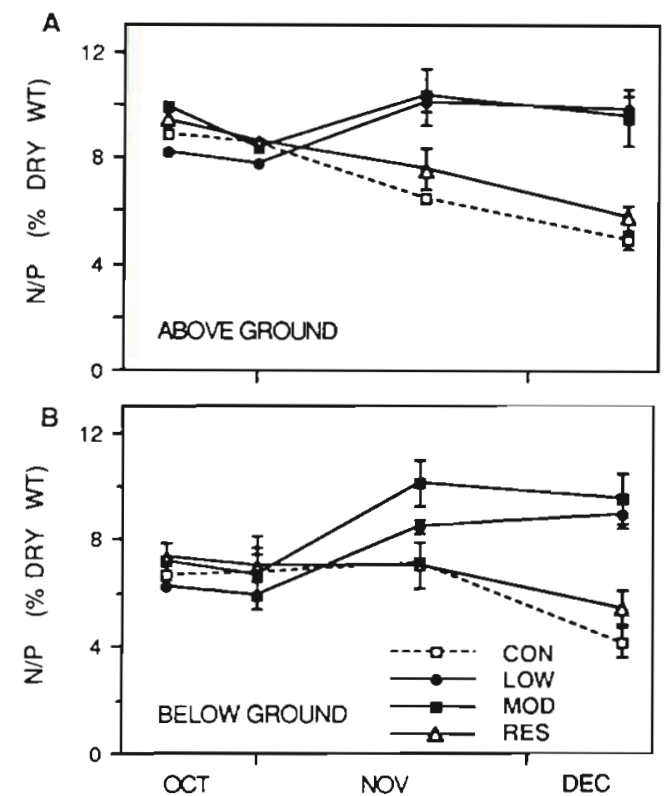

Fig. 9. Zostera marina. Tissue N/P ratios of eelgrass during the fall experiment. Data are given as means $\pm 1 \mathrm{SE}$ for (A) aboveground and (B) belowground tissue

\section{DISCUSSION}

These experiments demonstrate that under conditions simulating poorly flushed coastal habitat, even low levels of chronic, water-column nitrate enrichment can promote the decline of eelgrass. In the North Carolina area, adverse effects of nitrate enrichment were exacerbated during the spring growing season under increasing temperatures and reduced light from proliferating macroalgae. In spring our mesocosms all maintained similar temperature and (decreasing) light availability, but Zostera marina declined even in low water-column nitrate enrichment, with more dramatic effects under increased nitrate loading. During autumn, Z. marina declined under low/moderate water-column nitrate enrichment despite decreasing temperatures, relatively low macroalgal abundances, and moderate to high light availability. The data strongly indicate that long-term nitrate additions (weeks to months) cause eelgrass decline as a direct physiological effect, likely enhanced by increasing temperatures and light reduction.

Although the physiological mechanism(s) involved remain to be determined, the 'crumbling' meristems on shoots with intact bright green leaves and the tissue nutrient content provide intriguing clues. Imbalances in ratios of nutrient supplies (C/N, N/P) are significant in determining community composition and species survival among phytoplankton, macroalgae and rooted angiosperms in freshwater, estuarine and marine habi-

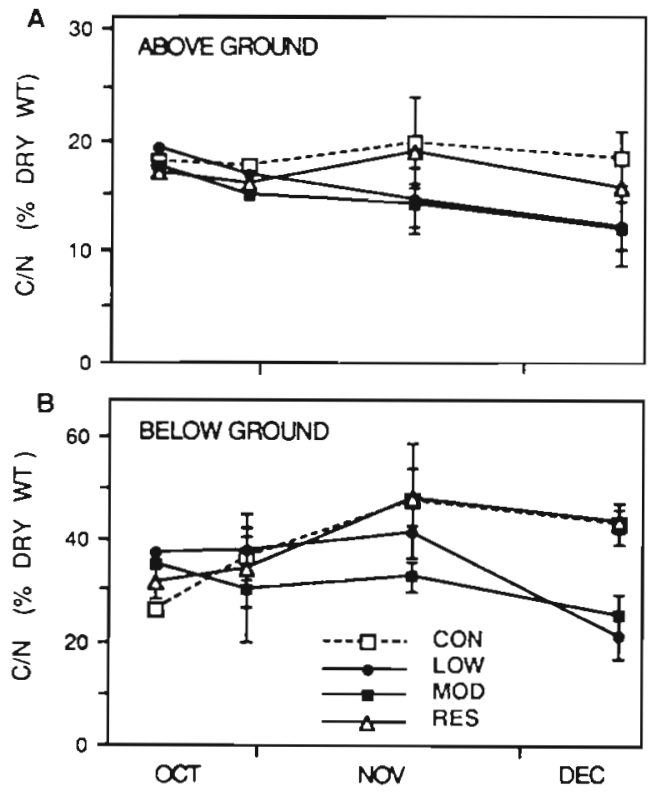

Fig. 10. Zostera marina. Tissue $C / N$ ratios of eelgrass during the fall experiment (data given as in Fig. 9)

tats (Gerloff \& Krombholz 1966, Atkinson \& Smith 1983, Kilham \& Kilham 1984, Smayda 1989). Zostera marina has also been inferred to respond to imbalances in nutrient supplies, on the basis of its C, N, and $P$ content (Atkinson \& Smith 1983, Duarte 1990). Hence, hypotheses which merit consideration in explaining our observations are that chronic watercolumn nitrate enrichment causes eelgrass decline by forcing the plants into carbon limitation, phosphorus limitation, or other severe internal nutrient imbalance.

In both seasons the data indicate that Zostera marina took up pulsed nitrate from the water as it became available. This premise is supported by Roth \& Pregnalls' (1988) short-term experiments with eelgrass from shallow sandy field habitat, wherein shoots sustained high nitrate uptake from enriched water through a 6 d period. As there is little intercellular space available for nitrate accumulation (den Hartog 1970), within the leaf tissue high quantities of nitrate would have been converted into ammonia either immediately or following vacuolar storage. Ammonia production, in turn, would have required the plant to shunt substantial carbon resources for immediate conversion into amino acids (Salisbury \& Ross 1978 , Turpin 1991). If high nitrate uptake was maintained for an extended period (e.g. weeks), then despite nonlimiting light availability and abundant carbon in the medium, perhaps the plants were not able to fix enough carbon to support their total carbon demand. The aboveground meristem likely would be severely 
affected if insufficient carbon was available for structural growth, whereas mature leaves that formed prior to the onset of carbon stress would be expected to retain structural integrity. Eventually, toxic levels of ammonia could accumulate under high nitrate uptake, especially if the plants began to become depleted in carbon supplies for amino acid production (Salisbury \& Ross 1978). Physiological stress from imbalances in nutrient supplies can result in accumulation of ammonia as well as other toxic metabolites in the meristematic region (Levitt 1980). Phosphorus limitation could become an additional contributing factor in eelgrass decline under sustained uptake of water-column nitrate as internal nutrient supply ratios shifted, and as $P$ was increasingly consumed in active nitrate transport, amino acid synthesis, and other energy-requiring processes associated with elevated nitrate uptake (Tilman et al. 1982, Turpin 1991)

These or related mechanisms may be operative in effecting eelgrass disappearance from quiet embayments and poorly flushed lagoons, which can receive much higher loading than that imposed in our low or moderate enrichments (Mahoney \& Gibson 1983, Ramus \& Venable 1987, Maier \& Pregnall 1990, Neckles 1990). Following physiological stresses imposed by nutrient supply imbalances, $N_{1}$ enrichment may secondarily affect weakened plants by enhancing susceptibility to opportunistic pathogens such as Labyrinthula. Eelgrass and other angiosperms are known to decrease production of anti-microbial phenolics while increasing protein synthesis in $\mathrm{N}_{\mathrm{i}}$-enriched, lightreplete conditions (Bazzaz et al, 1987, Buchsbaum et al. 1990).

Observations by other researchers suggest potential synergistic interactions between water-column nitrate and suspended sediment loading (or other source of light reduction, such as macroalgal overgrowth) in adversely affecting eelgrass. In Chesapeake Bay, for example, eelgrass has declined in early summer following turbid spring conditions with relatively high nitrate inputs (Kemp et al. 1983, Orth et al. 1986, Moore et al. 1989). This decline may have occurred, in part, because the plants were unable to store sufficient carbon under the former light limitation and elevated nitrate. Carbon stress would be exacerbated particularly under increasing/high temperatures, which would increase respiration and consumption of stored carbohydrates that would otherwise have been available for other biosynthesis requirements (Zimmerman et al. 1989). Other angiosperms in flooded anaerobic sediments enriched with nitrate have been shown to increase carbohydrate consumption by the root tissue (Bertani et al. 1987). If operative in Zostera marina, this activity would also decrease availability of carbon reserves to aboveground tissue. Moreover, high tem- peratures would inactivate translocation enzymes that normally shunt stored carbon from the rhizome to the aboveground meristem (Zimmerman et al. 1987, 1989). The hypothesis of Zimmerman et al. (1989) that rootzone anoxia may inactivate these carbon translocation enzymes should apply to eelgrass in deeper locations with muddy sediments high in sulfide, but would be less likely for photosynthesizing plants in shallow, sandier habitat similar to that of the mesocosms, with sediments that are aerobic for some distance from the rhizosphere following lacunar transport of oxygen from aboveground to belowground tissue (King \& Klug 1982, Penhale \& Wetzel 1982).

Eelgrass roots typically encounter high ammonia and nitrate (Kenworthy et al. 1982, Short \& McRoy 1982, Short 1987). The highest water-column enrichment regime in our spring experiment resulted in significantly greater sediment $\mathrm{NO}_{3}{ }^{-} \mathrm{N}$ storage at depth $(10 \mathrm{~cm},>5 \mathrm{~cm}$ below most of the eelgrass roots and rhizomes) than in controls or other treatments, but higher sediment concentrations commonly occur in the field (Kenworthy et al. 1982, Short \& McRoy 1982). Benthic denitrifiers would be expected to strongly mediate $\mathrm{N}_{\mathrm{i}}$ supplies to the roots while other microbial decomposers increased the availability of phosphorus and other nutrients (Smith et al. 1984, Caffrey \& Kemp 1990). By comparison, such microbial controls would be much less effective at reducing nitrate concentrations in the enriched and well-oxygenated water column (Koike \& Sorensen 1988, Paasche 1988).

Our experiments demonstrated that there is a strong effect of season on the response of macroalgae as well as eelgrass to increasing water-column nitrate. Decreased macroalgal production in the high nitrate regime relative to that in the low or moderate enrichments suggests that the macroalgae may also have encountered some degree of nitrate inhibition (Steffensen 1976), but at much higher loadings than Zostera marina. Rapidly growing macroalgae such as Enteromorpha and Ectocarpus were more highly stimulated in spring, and they may have beneficially affected eelgrass by acting as nutrient 'sponges' (Harlin 1978) while also adversely affecting $Z$. marina in all of the mesocosms by reducing light. The seasonal differences in macroalgal response may have been related, in part, to inherent seasonality of the dominant taxa. On the North Carolina coast, all Ectocarpus spp. and most Enteromorpha spp. are cold-optimal with highest abundances of field populations attained in winterearly spring, whereas Chaetomorpha linum and Cladophora montagneana are generally considered late summer-autumn forms (Schneider \& Searles 1991). Like other 'weedy' taxa, these genera can respond quickly to pulsed nutrient additions (Ramus \& Venable 1987). Herbivore abundances in the meso- 
cosms were low or moderate relative to field densities, and it is probable that higher grazing pressure would have reduced algal biomass particularly during the fall season of increased herbivore activity (Orth \& van Montfrans 1984, Neckles 1990). However, natural populations of algal grazers (e.g. many gastropods and amphipods) generally are low in spring (Zimmerman et al. 1979, Orth \& van Montfrans 1984). Hence, herbivory likely would be inadequate to control these nuisance algae in the spring season of maximal growth, especially under nutrient stimulation.

It might be argued that the direct adverse effects of water-column nitrate enrichment on eelgrass would be less severe in cooler climates under more optimal temperatures for growth. Osmond (1987) encouraged physiological research on plants 'at the edges of their geographical range... as a means of understanding their responses to stress and disturbance.' While the threshold concentrations may vary with geographic region, we predict that nitrate inhibition from watercolumn enrichment also plays a significant role in determining the survival of eelgrass meadows in more northern areas such as New England, where Harlin \& Thorne-Miller (1981) described the complete disappearance of dense eelgrass growth in a wide ring around nitrate-leaching pots. These researchers additionally reported that, whereas eelgrass production was stimulated with ammonium or phosphate enrichments, increased growth did not occur with nitrate along diffusive gradients even at some distance from the enrichment source. The present study indicates that, for eelgrass, nitrate should be regarded as more than a potential source of nutrient in $\mathrm{N}$-limited coastal habitat, and as more than an indirect source of algal turbidity. Instead, chronic exposure to nitrate-enriched waters is directly lethal to Zostera marina even at low enrichment levels, and likely represents an important causative agent in the disappearance of eelgrass meadows from many quiet embayments and coastal lagoons throughout the world.

Acknowledgments. Funding support for the 1990 research was provided by the Office of Sea Grant, NOAA, U.S. Dept. of Commerce (Grant No. NA90AA-D-SG062), and the UNC Sea Grant College (Project No. R/MER-17), with additional support from the NC Agricultural Research Foundation (Project No. 06034), the NC Agricultural Research Service (Project No. 06188), and the Dept. of Botany at NCSU. Many people helped to make the 1990 experiments possible. B. $J$. Copeland's encouragement helped greatly throughout this project. W. F. Cross was our host on the NMFS grounds and graciously provided electricity and research space, with laboratory space also provided by W. Hettler, D. Hoss, C. Manooch and P. Tester. J. Russell helped troubleshoot and improve our mesocosm facility, assisted by $D$. Lewis. The 1990 field plant collections were made possible by $M$. Fonseca, whose counsel throughout the project is much appreciated. Transplanting efforts involved at least 22 volunteers, with extensive assistance from V. Coleman, C. Hobbs, G. Morgan, J. Priddy, D. Squires, L. Taggett and B. Walker. D. Squires helped monitor the system, with additional assistance from $J$ Green, J. Luczkovich, M. Mallin and W. Riggsbee. We thank B. Bebout for his instruction in sediment pore-water sampling, and $\mathrm{H}$. Paerl for use of associated facilities. D. Kamykowski and R. Reed provided use of an autoanalyzer. L. Crowder and B. Walker contributed herbivore analyses, and L. Taggett completed fall plant growth analyses. C. Brownie advised us extensively on all statistics. K. Bird, U. Blum, V. Coleman, M. Mallin, M. McAuley, M. Pregnall, D. Tomasko, T. Wentworth, R. C. Zimmerman, and 2 anonymous colleagues kindly reviewed the manuscript.

\section{LITERATURE CITED}

Alberts, E. E., Moldenhauer, W. C. (1981). Nitrogen and phosphorus transported by eroded soil aggregates. Soil Sci. Soc. Am. J. 45: 391-396

Atkinson, M. J., Smith S. V. (1983). C:N:P ratios of benthic marine plants. Limnol. Oceanogr. 28: 568-574

Bazzaz, F. A., Chiariello, N. R., Coley, P. D., Pitelka, L. F. (1987). Allocating resources to reproduction and defense. BioScience 37: 58-67

Bertani, A., Brambilla, I., Reggiani, R. (1987). Effect of exogenous nitrate on anaerobic root metabolism. In: Crawford, R. M. M. (ed.) Plant life in aquatic and amphibious habitats. Blackwell Scientific Publications, Boston, p. 255-264

Borum, J. (1985). Development of epiphytic communities on eelgrass (Zostera marina) along a nutrient gradient in a Danish estuary. Mar. Biol. 87: 211-218

Buchsbaum, R. N., Short, F. T., Cheney, D. P. (1990). Phenolicnitrogen interactions in eelgrass (Zostera marina L.): possible implications for disease resistance. Aquat. Bot. 37 : 291-297

Burkholder, J. M., Sheath, R. G. (1985). Characteristics of softwater streams in Rhode Island. I. A comparative analysis of physical and chemical variables. Hydrobiologia 128 : 97- 108

Burkholder, J. M., Wetzel, R. G. (1989). Epiphytic microalgae on natural substrata in a hardwater lake: seasonal dynamics of community structure, biomass and ATP content. Arch. Hydrobiol. (Suppl,) 83: 1-56

Caffrey, J. M., Kemp, W. M. (1990). Nitrogen cycling in sediments with estuarine populations of Potamogeton perfoliatus and Zostera marina. Mar. Ecol. Prog. Ser. 66 $147-160$

Cambridge, M. L., McComb, A. J (1984). The loss of seagrasses from Cockburn Sound, Western Australia. I. The time course and magnitude of seagrass decline in relation to industrial development. Aquat. Bot. 20: 229-243

Craig, N. J., Kuenzler, E. J. (1983). Land use, nutrient yield, and eutrophication in the Chowan River Basin. Report No. 205. North Carolina Water Resources Research Institute, Raleigh, North Carolina

Crowder, L. B., Cooper, W. E. (1982). Habitat structural complexity and the interaction between bluegills and their prey. Ecology 62: 1802-1813

Day, R. W., Quinn, G. P. (1989). Comparisons of treatments after an analysis of variance in ecology. Ecol. Monogr. 59 $433-463$

Den Hartog, C. (1970). The sea-grasses of the world. North Holland, Amsterdam 
Dennison, W. C. (1987). Effects of light on seagrass photosynthesis, growth and depth distribution. Aquat. Bot. 27: $15-26$

Dennison, W. C., Alberte, R. S. (1982). Photosynthetic responses of Zostera marina L. (eelgrass) to in situ manipulations of light intensity. Oecologia 55: 51-61

Duarte, C. M. (1990). Seagrass nutrient content. Mar Ecol. Prog. Ser. 67: 201-207

Ferguson, R. L., Rivera, J. A., Wood, L. L. (1988). Submerged aquatic vegetation in the Albemarle-Pamlico Estuarine System. Project No. 88-10. National Marine Fisheries Service, National Oceanic \& Atmospheric Administration

Fonseca, M. S., Kenworthy, W. J., Thayer, G. W., Heller, D. Y., Cheap, K. M. (1985). Transplanting of the seagrasses Zostera marina and Halodule wrightii for sediment stabilization and habitat development on the East Coast of the United States. Technical Report EL-85-9. Dept. of the Army, U.S. Army Corps of Engineers, Washington, D.C.

Froelich, P. N. (1988). Kinetic control of dissolved phosphate in natural rivers and estuaries: a primer on the phosphate buffer mechanism. Limnol. Oceanogr. 33: 649-668

Gerloff, G. C., Krombholz, P. H. (1966). Tissue analysis as a measure of nutrient availability for the growth of angiosperm aquatic plants. Limnol. Oceanogr. 11: $529-537$

Giesen, W. B. J. T., van Katwijk, M. M., den Hartog, C. (1990). Eelgrass condition and turbidity in the Dutch Wadden Sea. Aquat. Bot. 37: 71-85

Gill, J. L. (1978). Design and analysis of experiments in the animal and medical sciences. Vols. 1, 2 and 3. Iowa State University Press, Ames

Grasshoff, K., Ehrhardt, M., Kremling, K. (1983). Methods of seawater analysis. Springer-Verlag, Berlin

Grobbelaär, J. U. (1983). Availability to algae of $\mathrm{N}$ and $\mathrm{P}$ adsorbed on suspended solids in turbid waters of the Amazon River. Arch. Hydrobiol. 96: 301-316

Harlin, M. M. (1978). Nitrate uptake by Enteromorpha spp. (Chlorophyceae): applications to aquaculture systems. Aquaculture 15: 373-376

Harlin, M. M., Thorne-Miller, B. (1981). Nutrient enrichment of seagrass beds in a Rhode Island coastal lagoon. Mar Biol. 65: 221-229

Jacobs, T. C., Gilliam, J. W. (1985). Riparian losses of nitrate from agricultural drainage waters. J. environ. Qual. 14 $472-478$

Kemp, W. M., Twilley, R. R., Stevenson, J. C., Boynton, W. R., Means, J. C. (1983). The decline of submerged vascular plants in upper Chesapeake Bay: summary of results concerning possible causes. Mar. Technol. Soc. J. 17: 78-89

Kenworthy, W. J., Zieman, J. C., Thayer, G. W. (1982). Evidence for the influence of seagrasses on the benthic nitrogen cycle in a coastal plain estuary near Beaufort, North Carolina (USA). Oecologia 54: 152-158

Kilham, P., Kilham, S. S. (1984). The importance of resource supply rates in determining phytoplankton community structure. In: Meyers, D. G., Strickler, J. R. (eds.) Trophic interactions within aquatic ecosystems. AAAS Selected Symposium 85, Washington, D.C., p. 7-27

King, G. , Klug, M. J. (1982). Relation of soil water movement and sulfide concentration to Spartina alterniflora production in a Georgia salt marsh. Science 220: 61-63

Koike, I., Sorensen, J. (1988). Nitrate reduction and denitrification in marine sediments. In: Blackburn, T. H., Sorensen, J. (eds.) Nitrogen cycling in coastal marine environments. John Wiley \& Sons, New York, p. 251-274

Kristensen, E. (1988). Benthic fauna and biogeochemical processes in marine sediments:microbial activities and fluxes.
In: Blackburn, T. H., Sorensen, J. (eds.) Nitrogen cycling in coastal marine sediments. John Wiley \& Sons, New York

Lambers, H. (1985). Respiration in intact plant tissues: its regulation and dependence on environmental factors, metabolism and invaded organisms. In: Douce, R., Day, D. A. (eds.) Encyclopedia of plant physiology. New series. Higher plant cell respiration. Springer-Verlag, Berlin, p. $418-474$

Levitt, J. (1980). Responses of plants to environmental stresses. Vol. II. Water, radiation, salt, and other stresses. 2nd edn. Academic Press, New York

Lund, J. W. G., Kippling, C. LeCren, E. D. (1958). The inverted microscope method of estimating algal numbers and the statistical bias of estimations by counting. Hydrobiologia 11: $143-170$

Mahoney, R. K., Gibson, R. A. (1983). Phytoplankton ecology of the Indian River near Vero Beach, Florida. Fl. Sci. 46: $212-232$

Maier, C. M., Pregnall, A. M. (1990). Increased macrophyte nitrate reductase activity as a consequence of groundwater input of nitrate through sandy beaches. Mar. Biol. 107: $263-271$

Mallin, M.A., Paerl, H.W, Rudek, J. (1991). Seasonal phytoplankton composition, productivity and biomass in the Neuse River Estuary, North Carolina. Estuar. coast. Shelf Sci. 32: 609-623

Marsh, J. A., Dennison, W. C., Alberte, R. S. (1986). Effects of temperature on photosynthesis and respiration in eelgrass (Zostera marina L.). J. exp. mar. Biol. Ecol. 101: $257-267$

McRoy, C. P., McMillan, C. (1977). Production ecology and physiology of seagrasses. In: McRoy, C. P., Helfferich, C. (eds.) Seagrass ecosystems: a scientific perspective. Marcel Dekker, New York, p. 53-88

Merideth, M. P., Stehman, S. V. (1990). Repeated measures experiments in forestry: focus on analysis of response curves. Can. J. For. Res. 21:957-965

Morris, I. (1974). Nitrogen assimilation and protein synthesis. In: Stewart, W. D. P. (ed.) Algal physiology and biochemistry. Botanical Monographs Vol. 10. University of California Press, Berkeley, p. 583-609

Mueller-Dombois, D., Ellenberg, H. (1974). Aims and methods of vegetation ecology. Wiley Interscience, New York

National Oceanic and Atmospheric Administration (1980-1990). Local climatic data monthly summaries for Beaufort, North Carolina, and water temperature data for Beaufort Inlet. National Environmental Satellite, Data and Information Service, and National Marine Fisheries Service (W. Hettler), Beaufort

Neckles, H. A. (1990). Relative effects of nutrient enrichment and grazing on epiphyton-macrophyte (Zostera marina L.) dynamics. Ph.D. dissertation. Virginia Institute of Marine Science, Gloucester Point

Newell, S. Y. (1982). Fungi and bacteria in or on leaves of eelgrass (Zostera marina L.) from Chesapeake Bay. In: Wetzel, R. L. (ed.) Structural and functional aspects of the ecology of submerged aquatic macrophyte communities in the lower Chesapeake Bay. Vol. 1. Spec. Rep. Appl. Mar. Sci. Ocean Eng. 267. Virginia Institute of Marine Sciences, Gloucester Point, p. 152-164

Orth, R. J. (1977). Effect of nutrient enrichment on growth of eelgrass Zostera marina in the Chesapeake Bay, Virginia, USA. Mar. Biol. 44: 187-194

Orth, R. J., van Montfrans, J. (1984). Epiphyte-seagrass relationships with an emphasis on the role of micrograzing: a review. Aquat. Bot. 18: 43-70 
Orth, R. J., Simons, J., Capelli, J., Carter, V., Hindman, L. Hodges, S., Moore, K., Rybicki, N. (1986). Distribution of submerged aquatic vegetation in the Chesapeake Bay and tributaries - 1985. Final Report. United States Environmental Protection Agency, Washington, D.C.

Osmond, C. B. (1987). Photosynthesis and carbon economy of plants. New Phytol. 106 (Suppl.): $161-175$

Parsons, T. R., Maita, Y., Lalli, C. M. (1985). A manual of chemical and biological methods for seawater analysis. Pergamon Press, New York

Paasche, E. (1988). Pelagic primary production in nearshore waters. In: Blackburn, T. H., Sorensen, J. (eds.) Nitrogen cycling in coastal marine environments. John Wiley \& Sons, New York, p. 33-58

Penhale, P. (1977). Macrophyte-epiphyte biomass and productivity in an eelgrass (Zostera marina L.) community. J. exp. Mar. Biol. Ecol. 26: 211-224

Penhale, P., Wetzel, R. G. (1982). Structural and functional adaptations of eelgrass (Zostera marina L.) to the anaerobic sediment environment. Can. J. Bot. 61: 1421-1428

Potvin, C., Lechowicz, M. J. (1990). The statistical analysis of ecophysiological response curves obtained from experiments involving repeated measures. Ecology 71: $1389-1400$

Pregnall, A. M., Smith, R. D., Alberte, R. S. (1987). Glutamine synthetase activity and free amino acid pools of eelgrass (Zostera marina L.) roots. J. exp. mar. Biol. Ecol. 106: $211-228$

Ramus, J., Venable, M. (1987). Temporal ammonium patchiness and growth rates in Codium and Ulva (Ulvophyceae). J. Phycol. 23: 518-523

Roth, N. C., Pregnall, A. M. (1988). Nitrate reductase activity in Zostera marina. Mar. Biol. 99:457-463

Rowell, J. G., Walters, D. E. (1976). Analyzing data with repeated observations on each experimental unit. J. agric. Sci. 87: 423-432

Rudek, J., Paerl, H. W., Mallin, M. A., Bates, P. W. (1991). Seasonal and hydrological control of phytoplankton nutrient limitation in the Neuse River Estuary, North Carolina. Mar. Ecol. Prog. Ser. 75: 133-142

Salisbury, F. B., Ross, C. W. (1978). Plant physiology. 2nd edn. Wadsworth Publishing Company, Inc., Belmont

SAS Institute, Inc. (1987). SAS/STAT guide for personal computers. Version 6. SAS Institute, Inc., Cary, North Carolina

Schneider, C. W., Searles, R. B. (1991). Seaweeds of the southeastern United States. Duke University Press, Durham

Short, F. T (1987). Effects of sediment nutrients on seagrasses: literature review and mesocosm experiment. Aquat. Bot. 27: 41-57

Short, F. T., McRoy, C. P. (1984). Nitrogen uptake by leaves and roots of the seagrass Zostera marina L. Bot. Mar. 27 $547-555$

Short, F. T., Ibelings, B. W., den Hartog, C. (1988). Comparison of a current eelgrass disease to the wasting disease of the 1930s. Aquat. Bot. 30: 295-304

Simon, N. S. (1989). Nitrogen cycling between sediment and shallow-water column in the transition zone of the Potomac River and Estuary. II. The role of wind-driven resuspension and absorbed ammonium. Estuar coast. Shelf Sci. 28: 531-547

Smayda, T J. (1989). Primary production and the global epidemic of phytoplankton blooms in the sea: a linkage? In: Cosper, E. M., Bricelj, V. M., Carpenter, E. J. (eds.) Novel

This article was presented by M. Hay, Morehead City, N. Carolina, USA phytoplankton blooms. Coastal and Estuarine Studies No. 35. Springer-Verlag, New York, p. 449-484

Smith, G. W., Hayasaka, S. S., Thayer, G. W. (1984). Ammonification of amino acids by the rhizoplane microflora of Zostera marina L. and Halodule wrightii Aschers. Bot. Mar. 27: 23-27

Stanley, D. H. (1988). Historical trends in nutrient loading to the Neuse River Estuary, N.C. In: Symposium on coastal water resources. American Water Resources Association, p. $155-164$

Steffensen, D. A. (1976). The effect of nutrient enrichment and temperature on the growth in culture of Ulva lactuca L. Aquat. Bot. 2: 337-351

Stevenson, J. C. (1988). Comparative ecology of submersed grass beds in freshwater, estuarine, and marine environments. Limnol. Oceanogr. 33: 867-893

Stumm, W., Morgan, J. J. (1981). Aquatic chemistry, 2nd edn Wiley, New York

Thayer, G. W., Kenworthy, W. J., Fonseca, M. S. (1984). The ecology of eelgrass meadows of the Atlantic Coast: a community profile. United States Department of the Interior Fish and Wildlife Service Report \#FWS/OBS-84/02. United States Department of the Interior, Washington, D.C.

Thursby, G. B., Harlin, M. M. (1982). Leaf-root interaction in the uptake of ammonia by Zostera marina. Mar. Biol. 72: 109-112

Tilman, D., Kilham, S. S., Kilham, P. (1982). Phytoplankton community ecology: the role of limiting nutrients. Ann. Rev. Ecol. Syst. 13: 349-372

Turpin, D. H. (1991). Effects of inorganic $N$ availability on algal photosynthesis and carbon metabolism. J. Phycol. 27: $14-20$

Twilley, R. R., Kemp, W. M., Staver, K. W., Stevenson, J. C., Boynton, W. R. (1985). Nutrient enrichment of estuarine submersed vascular plant communities. 1 Algal growth and effects on production of plants and associated communities. Mar. Ecol. Prog. Ser. 23: 179-191

van Montfrans, J., Wetzel, R. L., Orth, R. J. (1984). Epiphytegrazer relationships in seagrass meadows: consequences for seagrass growth and production. Estuaries 7: 289-309

Wetzel, R. L., Neckles, H. A. (1986). A model of Zostera marina L. photosynthesis and growth: simulated effects of selected physical-chemical variables and biological interactions. Aquat. Bot. 26: 307-323

Zieman, J. C., Wetzel, R. G. (1980). Productivity in seagrasses: methods and rates. In: Phillips, R. C., McRoy, C. P. (eds.) Handbook of seagrass biology: an ecosystem perspective. Garland Press, New York, p. 87-116

Zimmerman, R., Gibson, R., Harington, J. (1979). Herbivory and detritivory among gammaridean amphipods from a Florida seagrass community. Mar. Biol. 54: 41-47

Zimmerman, R. C., Reguzzoni, J. L., Wyllie-Echeverria, S. Josselyn, M., Alberte, R. S. (1991). Assessment of environmental suitability for growth of Zostera marina L. (eelgrass) in San Francisco Bay. Aquat. Bot. 39: 353-366

Zimmerman, R. C., Smith, R. D., Alberte, R. S. (1987). Is growth of eelgrass nitrogen-limited? A numerical simulation of the effects of light and nitrogen on the growth dynamics of Zostera marina. Mar. Ecol. Prog. Ser. 41 $167-176$

Zimmerman, R. C., Smith, R. D., Alberte, R. S. (1989). Thermal acclimation and whole-plant carbon balance in Zostera marina L. (eelgrass). J. exp. mar. Biol. Ecol. 130: 93-109

Manuscript first received: September 11, 1991 Revised version accepted: February 10, 1992 